\title{
Trace-gas metabolic versatility of the facultative methanotroph Methylocella silvestris
}

\author{
Andrew T. Crombie ${ }^{1} \&$ J. Colin Murrell ${ }^{1}$
}

The climate-active gas methane is generated both by biological processes and by thermogenic decomposition of fossil organic material, which forms methane and short-chain alkanes, principally ethane, propane and butane $e^{1,2}$. In addition to natural sources, environments are exposed to anthropogenic inputs of all these gases from oil and gas extraction and distribution. The gases provide carbon and/or energy for a diverse range of microorganisms that can metabolize them in both anoxic ${ }^{3}$ and oxic zones. Aerobic methanotrophs, which can assimilate methane, have been considered to be entirely distinct from utilizers of short-chain alkanes, and studies of environments exposed to mixtures of methane and multi-carbon alkanes have assumed that disparate groups of microorganisms are responsible for the metabolism of these gases. Here we describe the mechanism by which a single bacterial strain, Methylocella silvestris, can use methane or propane as a carbon and energy source, documenting a methanotroph that can utilize a short-chain alkane as an alternative to methane. Furthermore, during growth on a mixture of these gases, efficient consumption of both gases occurred at the same time. Two soluble di-iron centre monooxygenase (SDIMO) gene clusters were identified and were found to be differentially expressed during bacterial growth on these gases, although both were required for efficient propane utilization. This report of a methanotroph expressing an additional SDIMO that seems to be uniquely involved in short-chain alkane metabolism suggests that such metabolic flexibility may be important in many environments where methane and short-chain alkanes co-occur.

Most of the 500-600 Tg methane emitted into the atmosphere each year is of recent biological origin, whereas fossil-derived 'natural gas', from both anthropogenic and natural sources, contributes approximately $30 \%$ of the total ${ }^{4}$. Large anthropogenic releases of natural gas have included the Deepwater Horizon spill of 2010 (ref. 5), but intentional or unintentional operational releases are also widespread and likely to increase with the exploitation of unconventional resources, including shale gas extraction (fracking) ${ }^{6}$. A spectacular natural release, containing methane and $35 \%(\mathrm{v} / \mathrm{v})$ ethane and propane ${ }^{7}$, results in the 'eternal flame' in Chestnut Ridge Park, New York. Widespread seepage, which is largely undocumented, also occurs in terrestrial areas that overlay sedimentary organic carbon ${ }^{8}$. The natural geological methane source, including terrestrial macro-seeps and micro-seeps, marine seeps and volcanic and geothermal emissions, is the second largest natural source after wetlands. Micro-seeps, which are potentially active in substantial areas (including petroliferous regions and sedimentary basins where thermal degradation of organic material has occurred), contribute $10-25 \mathrm{Tg}$ methane annually ${ }^{8}$. This thermogenic natural gas contains methane and up to $50 \%(\mathrm{w} / \mathrm{w})$ ethane, propane and butane $\mathrm{e}^{1,2}$. In addition, unquantified biogenic production of ethane and propane occurs in anoxic environments similar to those that support methanogenesis and homoacetogenesis?.

Aerobic methanotrophs oxidize much of the methane that is released from terrestrial and marine environments before it reaches the atmosphere and are well characterized ${ }^{10}$, and microorganisms that grow on short-chain alkanes, including propane, have also received attention ${ }^{11-15}$.
However, so far, all evidence has emphasized the striking distinction between the groups of microorganisms performing these respective tasks. Aerobic methanotrophs are Gram-negative bacteria from about 16 genera within the Gammaproteobacteria and Alphaproteobacteria classes, as well as some extremophiles of the phylum Verrucomicrobia. Two types of enzyme that can oxidize methane are known: the membrane-associated particulate methane monooxygenase (pMMO), which was previously thought to be present in all methanotrophs; and a cytoplasmic, soluble form of this enzyme (sMMO), which is also present in a few extant strains. The sMMOs form one group of a large family of di-iron carboxylate enzymes that includes SDIMOs that allow growth on a range of short-chain alkanes, alkenes and aromatic compounds. Recently, a few methanotrophs were shown to have restricted growth on two-carbon compounds, including acetate ${ }^{16}$; however, there are no validated reports of growth on (as opposed to co-oxidation of) gaseous hydrocarbons other than methane. Short-chain alkane utilizers have been thought to be incapable of methane metabolism, and most are members of the class Actinobacteria ${ }^{12}$. An exception is Thauera butanivorans, which is a betaproteobacterium that grows on butane using a monooxygenase that is two to three orders of magnitude more specific for butane than for methane ${ }^{17}$, despite its sequence similarity (up to 65\%) to bona fide methane monooxygenases.

Methanotrophic strains of the genus Methylocella, first isolated from peat, tundra and forest soils in Northern Europe ${ }^{18}$, are widespread in a diverse range of terrestrial environments ${ }^{19}$ and have also been found, for example, among the microbial community following the Deepwater Horizon incident ${ }^{20}$. The ability of $M$. silvestris to grow on organic acids and alcohols is known, as are details of its $\mathrm{SMMO}^{18,21}$. Here we further investigated the metabolic potential of this organism (Extended Data Table 1$)$. M. silvestris grew on propane $(2.5 \%$ or $20 \%(\mathrm{v} / \mathrm{v}))$ at a similar rate to its growth solely on methane in batch culture (Table 1), reaching a high cell density in a fermenter supplied with $20 \%(\mathrm{v} / \mathrm{v})$ propane in air (Extended Data Fig. 1). It also grew on potential intermediates of propane oxidation: propionate, 2-propanol and acetone. Its growth on methane was not inhibited by the presence of $1 \%$ or $10 \%(\mathrm{v} / \mathrm{v})$ propane in the methane, and indeed the conversion of substrate carbon into biomass was slightly enhanced under both of these conditions of dual substrate

Table 1 | Growth rates of Methylocella silvestris strains

\begin{tabular}{cccc}
\hline \multirow{2}{*}{ Strain } & & \multicolumn{2}{c}{ Growth rate $\left(\mathrm{h}^{-1}\right)$} \\
\cline { 3 - 4 } Wild-type & Substrate & On 2.5\% $(\mathrm{v} / \mathrm{v})$ & On 20\% $(\mathrm{v} / \mathrm{v})$ \\
& Methane & $0.012 \pm 0.001$ & $0.013 \pm 0.003$ \\
& Propane & $0.005 \pm 0.000$ & $0.015 \pm 0.002$ \\
$\Delta \mathrm{MmoX}$ & Mixture & $0.011 \pm 0.001$ & $\mathrm{ND}$ \\
& Methane & No growth & No growth \\
& Propane & No growth & $0.010 \pm 0.000$ \\
$\Delta \mathrm{PrmA}$ & Mixture & No growth & $\mathrm{ND}$ \\
& Methane & $0.010 \pm 0.003$ & $0.019 \pm 0.005$ \\
& Propane & $0.003 \pm 0.000$ & No growth \\
& Mixture & $0.010 \pm 0.000$ & ND \\
\hline
\end{tabular}

Specific growth rates of wild-type $M$. silvestris and the $\triangle \mathrm{MmoX}$ and $\triangle \mathrm{PrmA}$ strains during growth on methane or propane (at the concentrations shown) or a mixture $(2.5 \%(\mathrm{v} / \mathrm{v})$ each). The data are the mean \pm s.d. of triplicate vials (except for $2.5 \%$ ( $v / v)$ propane, for which duplicate vials were used). ND, not determined.

${ }^{1}$ School of Environmental Sciences, University of East Anglia, Norwich Research Park, Norwich NR4 7TJ, UK. 


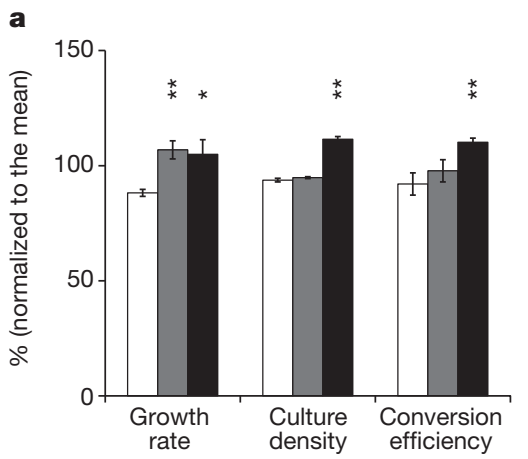

Figure $1 \mid$ Propane enhanced Methylocella silvestris growth, and methane and propane were consumed by cultures at rates corresponding to their relative concentrations. a, The specific growth rate $(\mu)$, maximum culture density (optical density at $540 \mathrm{~nm}\left(\mathrm{OD}_{540}\right)$ ) and carbon conversion efficiency (CCE) of cultures supplied with equimolar amounts of carbon as methane $(10 \%(\mathrm{v} / \mathrm{v})$, white) or mixtures of methane and propane (99:1 (v/v), grey; 90:10

availability (Fig. 1a). To identify any substrate preference, liquid cultures of $M$. silvestris supplied with various mixtures of methane and propane were monitored. The components of the gas mixtures, ranging from 1:10 to 100:1 (methane:propane), were differentially consumed in direct proportion to their relative headspace concentrations (Fig. 1b), with methane being consumed at a volumetric rate approximately 1.5 times that of propane when supplied at equivalent concentrations. The similar Henry's law coefficients ${ }^{22}$ of methane and propane $\left(K_{\mathrm{H}}=1.3 \times 10^{-3}\right.$ and $1.4 \times 10^{-3} \mathrm{M} \mathrm{atm}^{-1}$, respectively) and consequent aqueous concentrations indicated that the overall kinetic parameters in these microcosms were similar and that under these conditions $M$. silvestris did not exhibit a major substrate preference for either of these gases.

Analysis of the genome of M. silvestris ${ }^{23}$ confirmed the absence of the membrane-associated pMMO but revealed an SDIMO gene cluster in addition to that encoding sMMO. Phylogenetic analysis of the putative hydroxylase $\alpha$-subunit grouped this second SDIMO with those of propane-oxidizing bacteria, including Gordonia sp. TY-5 (ref. 14). These SDIMOs belong to Group V SDIMO enzymes as defined by Coleman and co-workers ${ }^{24}$ (Extended Data Fig. 2a), suggesting that in M. silvestris this gene cluster might encode a propane monooxygenase (PrMO).

Transcription of this SDIMO was confirmed by reverse-transcription PCR (RT-PCR); $5^{\prime}$ rapid amplification of cDNA ends (RACE) was used to identify the transcription start site, which is 120 nucleotides upstream $\left(5^{\prime}\right)$ of the predicted start codon, and a putative $\sigma^{54}$ promoter was located (Extended Data Fig. 2b). A reporter gene (green fluorescent protein (GFP)) under the control of each of the putative promoters of these two enzyme systems (sMMO and PrMO) was then expressed in M. silvestris from plasmids: the sMMO genes, but not the PrMO genes, were transcribed during growth on methane, but both sets of genes were transcribed during growth on propane (Fig. 2). The protein profiles differed between these two growth conditions, and mass spectrometric analysis of bands excised from a gel confirmed that protein expression mirrored gene transcription (Extended Data Fig. 3a, b).

The sMMO from other methanotrophs can co-oxidize numerous substrates, including propane ${ }^{25}$, although these organisms cannot assimilate the oxidation products, whereas the specificity of $\operatorname{PrMO}$ is relatively unknown. Therefore, although methanotrophs have been notoriously difficult to genetically manipulate, two deletion mutants were constructed by targeted marker-exchange mutagenesis, to unravel the relative contribution of each enzyme to growth on alkanes. Wild-type M. silvestris and $M$. silvestris strain $\triangle \mathrm{MmoX}$ and strain $\triangle \mathrm{PrmA}$ (with deletions of the hydroxylase $\alpha$-subunits of sMMO and PrMO, respectively) were grown in batch culture on $20 \%(\mathrm{v} / \mathrm{v})$ methane or $20 \%(\mathrm{v} / \mathrm{v})$ propane. At this substrate concentration, the deletion strains did not grow on the gas for b

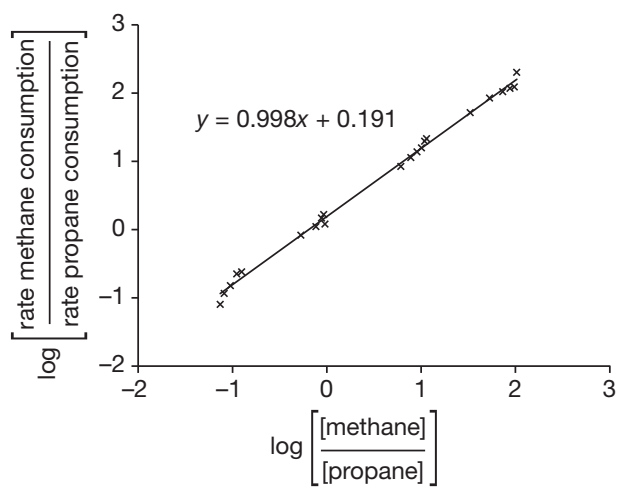

(v/v), black). The data are normalized to the mean $\left(\mu=0.018 \mathrm{~h}^{-1}\right.$, $\mathrm{OD}_{540}=0.36$ and $\mathrm{CCE}=0.28 \mathrm{mg}$ protein per $\mathrm{mg}$ substrate carbon); $n=3$ vials per growth condition. Error bars, s.d. Significance was determined by single factor analysis of variance (ANOVA) (compared with growth on $100 \%$ methane): *, $P<0.05$; **, $P<0.01)$. $\mathbf{b}$, Relative rates of methane and propane consumption by cultures supplied with a range of gas mixtures.

which they lacked the nominal oxidizing enzyme (Table 1). When cultures were supplied with $2.5 \%(\mathrm{v} / \mathrm{v})$ methane or $2.5 \%(\mathrm{v} / \mathrm{v})$ propane, the wild-type strain grew on both substrates. By contrast, the $\Delta \mathrm{MmoX}$ strain did not grow on $2.5 \%(\mathrm{v} / \mathrm{v})$ methane, $2.5 \%(\mathrm{v} / \mathrm{v})$ propane or a mixture of these $(2.5 \%(\mathrm{v} / \mathrm{v})$ of each). The $\Delta \operatorname{PrmA}$ strain grew on $2.5 \%(\mathrm{v} / \mathrm{v})$ methane similarly to the wild-type and, interestingly, also on $2.5 \%(\mathrm{v} / \mathrm{v})$ propane but at a reduced rate (Table 1) and with a $30 \%$ reduction in the conversion of the substrate carbon into biomass compared with the wild-type strain (Extended Data Fig. 4a). During growth on a mixture of methane and propane $(2.5 \%(\mathrm{v} / \mathrm{v})$ each), only a marginal difference in growth rate was observed between the wild-type and $\Delta \operatorname{PrmA}$ strains, and the $\Delta$ PrmA strain consumed both gases simultaneously, similarly to the wild-type strain, although a small decrease in the carbon conversion efficiency was evident (Fig. 3). We also noted that the carbon source (succinate or methane plus propane) for the cells used as the inoculum did not affect a culture's subsequent simultaneous oxidation of methane and propane (Extended Data Fig. 4b).
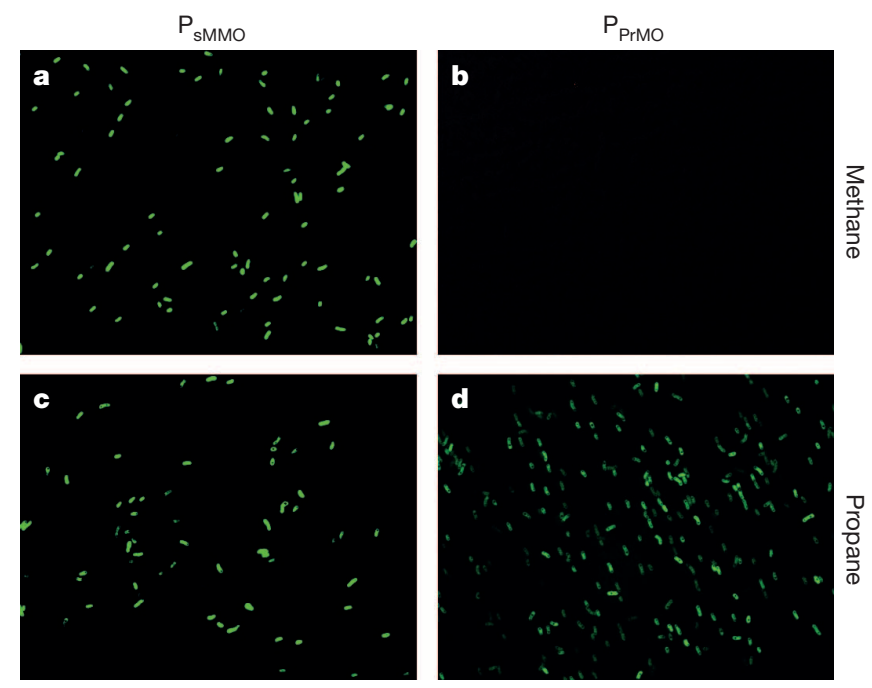

Figure $2 \mid$ Methane induced transcription of sMMO only, whereas propane induced both sMMO and PrMO. Fluorescence microscopy images of M. silvestris cells grown to late exponential phase on methane alone $(\mathbf{a}, \mathbf{b})$ or propane alone (c, d) transformed with plasmids containing the sMMO promoter (a, c) or the PrMO promoter (b, d) fused to a GFP (green) reporter gene. The images are representative of one of two independent experiments. Cells are approximately $1.5 \mu \mathrm{m}$ in length. 


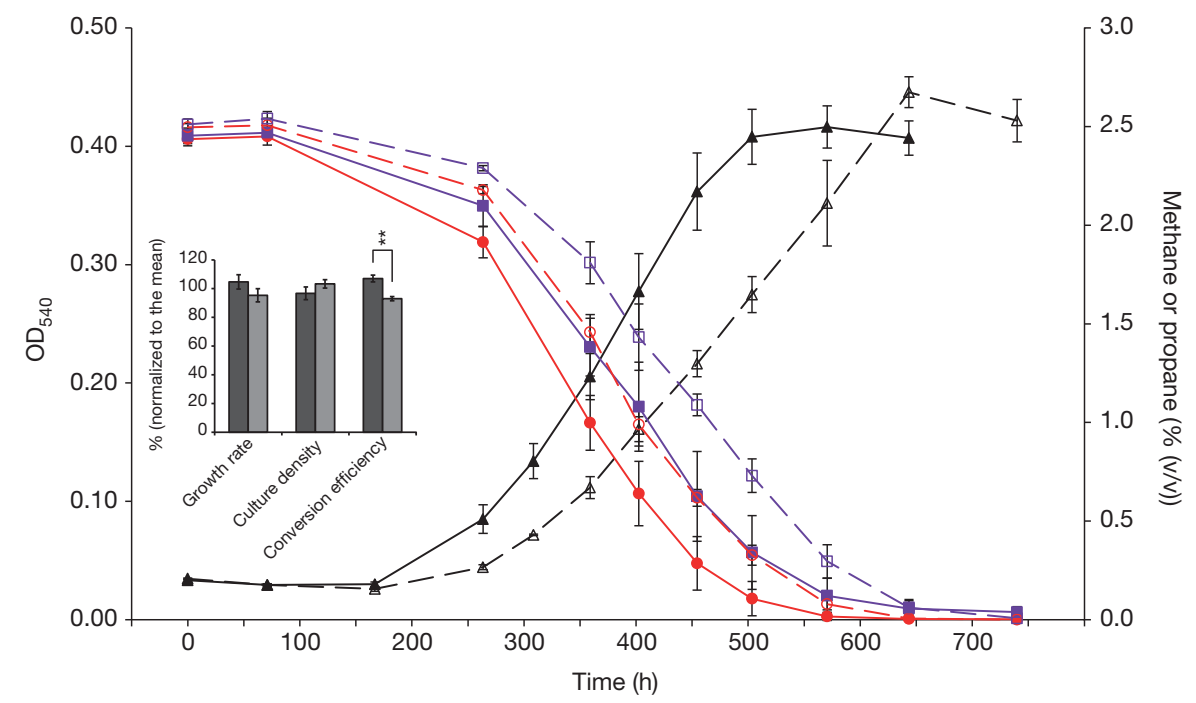

Figure 3 Inactivation of PrMO had a marginal effect during growth on a mixture of methane and propane. Growth (left $y$ axis, black lines) and substrate consumption (right $y$ axis, coloured lines) of wild-type M. silvestris (solid lines, filled symbols) and the $\triangle \operatorname{PrmA}$ strain (dashed lines, open symbols). The inoculum was grown on succinate. The experimental cultures were supplied with a mixture of methane and propane $(2.5 \%(\mathrm{v} / \mathrm{v})$ each). The headspace concentrations of methane (red) and propane (purple) were determined by gas chromatography. $n=3$ vials per strain. Error bars, s.d. The inset shows the growth parameters for the wild-type strain (dark grey) and the $\triangle \mathrm{PrmA}$ strain (light grey). The inset data are normalized to the mean $\left(\mu=0.010 \mathrm{~h}^{-1}, \mathrm{OD}_{540}=0.43\right.$ and $\mathrm{CCE}=0.30 \mathrm{mg}$ protein per $\mathrm{mg}$ substrate carbon); $n=3$ vials per strain. Error bars, s.d. Significance was determined by Student's $t$-test: **, $P<0.01$.
Because sMMO can oxidize both methane and propane, the converse ability of PrMO, to oxidize methane, was evaluated by comparing methane consumption by the wild-type and $\Delta \mathrm{MmoX}$ strains during growth on $20 \%(\mathrm{v} / \mathrm{v})$ propane in the presence of $2 \%(\mathrm{v} / \mathrm{v})$ methane. The wildtype strain consumed both gases in proportion to their relative concentrations, as expected, whereas there was no detectable consumption of methane by the $\Delta \mathrm{MmoX}$ strain (Extended Data Fig. $4 \mathrm{c}, \mathrm{d}$ ).

The relative inability of PrMO to oxidize methane was used to interpret the comparative substrate oxidation rates by whole cells of wildtype $M$. silvestris, as obtained by polarographic measurement of oxygen uptake in response to the addition of methane or propane, in an oxygen electrode. The maximum methane oxidation rates of cells grown on methane (expressing only sMMO) were 2.3-fold higher than those of cells grown on propane. By contrast, the maximum propane oxidation rates were 2.4-fold higher in propane-grown cells (expressing both sMMO and PrMO) than in methane-grown cells, indicating that in propane-grown cells, the propane-oxidizing ability was due mainly to PrMO (Extended Data Fig. 5a). Using this technique, methane-grown cells had an apparent Michaelis constant $\left(K_{\mathrm{m}}\right)$ of $53 \mu \mathrm{M}$ for methane, and propane-grown cells had an apparent $K_{\mathrm{m}}$ of $19 \mu \mathrm{M}$ for propane (Extended Data Fig. 5b, c). The relatively high affinity of PrMO for propane emphasizes its important role in propane oxidation and is consistent with the reduced growth rate of the $\Delta$ PrmA strain on this substrate. Therefore, $M$. silvestris contains two enzymes capable of propane oxidation, sMMO and PrMO, and deletion of PrMO is not sufficient to completely eliminate the oxidation of propane.

Bacterially mediated propane oxidation typically occurs at the terminal or sub-terminal carbon, producing 1-propanol or 2-propanol, respectively, or a mixture ${ }^{12}$. Terminal oxidation proceeds from 1-propanol to propanal and propionate, whereas 2-propanol is oxidized to acetone. Oxygen electrode assays demonstrated that, in comparison with cells grown on methane or succinate, propane-grown cells consumed threefold or fivefold more oxygen, respectively, in response to addition of 1propanol and propanal (Extended Data Fig. 6a), and growth tests indicated that 1-propanol-metabolizing ability was induced in propane-grown cells (Extended Data Fig. 7a-d). Quantitative label-free mass-spectrometric proteomic analyses showed that polypeptides of the methylmalonylCoA pathway of propionate oxidation were induced during growth on propane ${ }^{26}$, indicating terminal oxidation. However, 2 -propanol was detected in culture media, reaching a maximum of approximately $0.5 \mathrm{mM}$ at $200 \mathrm{~h}$ during growth on $4 \%(\mathrm{v} / \mathrm{v})$ propane, demonstrating that at least $25 \%$ of propane was oxidized at the sub-terminal position (Extended Data Fig. 8). When propane was depleted, 2-propanol was consumed by the cultures, and enzyme activities associated with the oxidation of sub-terminal intermediates were upregulated in propane-grown cells (Extended Data Fig. 6b, c). Therefore, in M. silvestris, propane was oxidized to both 1-propanol and 2-propanol. However, whereas 2-propanol (reaching $1.3 \mathrm{mM}$ at $1,050 \mathrm{~h}$ ) was also detected in the medium of the $\triangle \mathrm{PrmA}$ strain (grown on $4 \%$ (v/v) propane) (Extended Data Fig. 9a), it was not detected in the medium of the $\Delta \mathrm{MmoX}$ strain (grown on $20 \%(\mathrm{v} / \mathrm{v})$ propane). The sMMO of obligate methanotrophs has previously been shown to oxidize $n$-alkanes to a mixture of primary and secondary alcohols $^{25}$, and our data suggest that in M. silvestris, 2-propanol is a product of sMMO but not a major product of PrMO.

We therefore examined the protein expression pattern of the wildtype strain during growth on 2-propanol (Extended Data Fig. 3), and we observed that, under these conditions, PrMO, but not sMMO, was expressed. Therefore, these data suggest that propane oxidation by sMMO is sufficient for the induction of PrMO. The inability of the $\Delta \mathrm{MmoX}$ strain to grow at low propane concentrations probably resulted from a lack of sub-terminal metabolites, which may be responsible for the induction of PrMO expression. Interestingly, deletion of prmA also halved the growth rate of cultures on 2-propanol but had no significant effect on growth on methanol, ethanol, acetate or acetone (Extended Data Fig. 9b). A similar unexplained phenomenon has been noted by others ${ }^{14,27}$ after the genetic inactivation of propane-oxidizing enzymes in Gordonia and Mycobacterium spp. The decreased oxidizing ability, and consequent increased accumulation, of 2-propanol in the $\triangle \mathrm{PrmA}$ strain would also have contributed to its growth rate and carbon conversion efficiency being lower than those of the wild-type during growth on low concentrations of propane. Similarly, during incubation of this strain with higher propane concentrations, the 2-propanol that formed as a result of propane oxidation by sMMO may have accumulated to toxic levels, thereby inhibiting growth. This is consistent with PrMO having a role in the oxidation of 2-propanol, either directly or through a regulatory mechanism. To identify the ability of PrMO to directly participate in 2-propanol oxidation, and because acetylene is a potent irreversible inhibitor of $\mathrm{SDIMOs}^{28}$, we grew the wild-type strain on propane, 2-propanol or acetone in the presence or absence of $2 \%(\mathrm{v} / \mathrm{v})$ acetylene. Growth on propane was entirely prevented by the presence of acetylene, whereas growth on acetone was unaffected. Although this inhibition of PrMO reduced the specific growth rate of cultures supplied with 2-propanol by approximately $11 \%$ compared with uninhibited controls (Extended Data Fig. 9c), this reduction was far less than that caused by the gene deletion in the $\triangle$ PrmA strain, suggesting that the oxidation of 2-propanol by PrMO was relatively minor. Therefore, the exact mechanism by which PrMO is required for efficient 2-propanol metabolism remains to be elucidated.

To better understand the significance and role of facultative methanotrophs in the environment, we investigated the behaviour of whole cells in culture, rather than taking the more reductionist approach of analysing the specificities and kinetics of purified enzymes in vitro. The data indicated that sMMO was necessary and sufficient for growth on 
methane but that both SDIMOs were required for efficient metabolism of propane. Although sMMO was capable of propane oxidation, it did not exclusively perform this role, and cells lacking PrMO were at a disadvantage that increased with increasing substrate concentration. This report is to our knowledge the first to describe an organism that can grow on methane or a short-chain alkane, disproving the dogma that separate microorganisms are responsible for the metabolism of methane and other simple hydrocarbon gases, such as propane. The $p m o A$ gene, which encodes the $\alpha$-subunit of pMMO, has frequently been used as an environmental probe for methanotrophs ${ }^{29}$, raising the possibility that sMMO-only methanotrophs have been overlooked, and some of these might have similar capabilities to those described here. Given the widespread co-occurrence of methane and short-chain alkanes, including propane, in the environment, the potential for simultaneous oxidation of these gases may be considerable. This finding also has implications for studies of carbon cycling in environments where natural gas is released, such as the 8 million square kilometres of Earth's terrestrial regions, where micro-seeps may be abundant ${ }^{6}$, or near marine methane seeps, oil spills and gas extraction and distribution systems.

\section{METHODS SUMMARY}

Methylocella silvestris BL2 was grown in $20 \mathrm{ml}$ or $25 \mathrm{ml}$ volumes in $120-\mathrm{ml}$ serum vials sealed with rubber stoppers as previously described ${ }^{30}$ and supplied with methane or propane by injection through the septum into the headspace. Headspace gas concentrations were quantified by gas chromatography, as were metabolites after solvent extraction from culture medium. The carbon conversion efficiency was calculated as the ratio of culture protein production to substrate carbon depletion. DNA and RNA procedures followed standard methods, and transcriptional start sites were determined using RACE. GFP-expressing reporter strains were constructed as previously described ${ }^{21}$. For gel-based protein analysis, bands of interest were excised, and polypeptides were identified by mass spectrometry. Mutant strains were constructed as previously described ${ }^{30}$. Polarographic activity assays used a Clark-type oxygen electrode to track substrate-induced oxygen consumption.

Online Content Any additional Methods, Extended Data display items and Source Data are available in the online version of the paper; references unique to these sections appear only in the online paper.

\section{Received 13 June 2013; accepted 26 February 2014.}

\section{Published online 28 April 2014}

1. Etiope, G. \& Ciccioli, P. Earth's degassing: a missing ethane and propane source. Science 323, 478 (2009).

2. Mango, F. D., Hightower, J. W. \& James, A. T. Role of transition-metal catalysis in the formation of natural gas. Nature 368, 536-538 (1994).

3. Heider, J., Spormann, A. M., Beller, H. R. \& Widdel, F. Anaerobic bacterial metabolism of hydrocarbons. FEMS Microbiol. Rev. 22, 459-473 (1998)

4. Etiope, G., Lassey, K. R., Klusman, R. W. \& Boschi, E. Reappraisal of the fossil methane budget and related emission from geologic sources. Geophys. Res. Lett 35, L09307 (2008).

5. Reddy, C. M. etal. Composition and fate of gas and oil released to the water column during the Deepwater Horizon oil spill. Proc. Natl Acad. Sci. USA 109, 20229-20234 (2012).

6. Osborn, S. G., Vengosh, A., Warner, N. R. \& Jackson, R. B. Methane contamination of drinking water accompanying gas-well drilling and hydraulic fracturing. Proc. Natl Acad. Sci. USA 108, 8172-8176 (2011).

7. Etiope, G., Drobniak, A. \& Schimmelmann, A. Natural seepage of shale gas and the origin of 'eternal flames' in the Northern Appalachian Basin, USA. Mar. Petrol. Geol. 43, 178-186 (2013).

8. Etiope, G. \& Klusman, R. W. Microseepage in drylands: flux and implications in the global atmospheric source/sink budget of methane. Glob. Planet. Change 72, 265-274 (2010).

9. Hinrichs, K. U. et al. Biological formation of ethane and propane in the deep marine subsurface. Proc. Natl Acad. Sci. USA 103, 14684-14689 (2006).
10. Reeburgh, W. S. in Treatise on Geochemistry (eds Holland, H. D. \& Turekian, K. K.) 1-32 (Elsevier, 2007)

11. Hamamura, N. \& Arp, D. J. Isolation and characterization of alkane-utilizing Nocardioides sp. strain CF8. FEMS Microbiol. Lett. 186, 21-26 (2000).

12. Ashraf, W., Mihdhir, A. \& Murrell, J. C. Bacterial oxidation of propane. FEMS Microbiol. Lett. 122, 1-6 (1994).

13. Kotani, T., Kawashima, Y., Yurimoto, H., Kato, N. \& Sakai, Y. Gene structure and regulation of alkane monooxygenases in propane-utilizing Mycobacterium sp. TY-6 and Pseudonocardia sp. TY-7. J. Biosci. Bioeng. 102, 184-192 (2006).

14. Kotani, T., Yamamoto, T., Yurimoto, H., Sakai, Y. \& Kato, N. Propane monooxygenase and $\mathrm{NAD}^{+}$-dependent secondary alcohol dehydrogenase in propane metabolism by Gordonia sp. strain TY-5. J. Bacteriol. 185, 7120-7128 (2003).

15. Johnson, E. L. \& Hyman, M. R. Propane and $n$-butane oxidation by Pseudomonas putida GPo1. Appl. Environ. Microbiol. 72, 950-952 (2006).

16. Semrau, J. D., DiSpirito, A. A. \& Vuilleumier, S. Facultative methanotrophy: false leads, true results, and suggestions for future research. FEMS Microbiol. Lett. 323, 1-12 (2011).

17. Cooley, R. B., Dubbels, B. L., Sayavedra-Soto, L. A., Bottomley, P. J. \& Arp, D. J. Kinetic characterization of the soluble butane monooxygenase from Thauera butanivorans, formerly 'Pseudomonas butanovora'. Microbiology 155, 2086-2096 (2009).

18. Dedysh, S. N., Knief, C. \& Dunfield, P. F. Methylocella species are facultatively methanotrophic. J. Bacteriol. 187, 4665-4670 (2005).

19. Rahman, M. T. et al. Environmental distribution and abundance of the facultative methanotroph Methylocella. ISME J. 5, 1061-1066 (2011).

20. Mason, O. U. et al. Metagenome, metatranscriptome and single-cell sequencing reveal microbial response to Deepwater Horizon oil spill. ISME J. 6, 1715-1727 (2012).

21. Theisen, A. R. et al. Regulation of methane oxidation in the facultative methanotroph Methylocella silvestris BL2. Mol. Microbiol. 58, 682-692 (2005).

22. Mackay, D. \& Shiu, W. Y. A critical review of Henry's law constants for chemicals of environmental interest. J. Phys. Chem. Ref. Data 10, 1175-1199 (1981).

23. Chen, Y.etal. Complete genome sequence of the aerobic facultative methanotroph Methylocella silvestris BL2. J. Bacteriol. 192, 3840-3841 (2010).

24. Coleman, N. V., Bui, N. B. \& Holmes, A. J. Soluble di-iron monooxygenase gene diversity in soils, sediments and ethene enrichments. Environ. Microbiol. 8 1228-1239 (2006).

25. Colby, J., Stirling, D. I. \& Dalton, H. The soluble methane mono-oxygenase of Methylococcus capsulatus (Bath). Its ability to oxygenate $n$-alkanes, $n$-alkenes, ethers, and alicyclic, aromatic and heterocyclic compounds. Biochem. J. 165, 395-402 (1977)

26. Patel, N. A. et al. Comparison of one- and two-dimensional liquid chromatography approaches in the label-free quantitative analysis of Methylocella silvestris. J. Proteome Res. 11, 4755-4763 (2012)

27. Furuya, T., Hirose, S., Osanai, H., Semba, H. \& Kino, K. Identification of the monooxygenase gene clusters responsible for the regioselective oxidation of phenol to hydroquinone in mycobacteria. Appl. Environ. Microbiol. 77, 1214-1220 (2011)

28. Prior, S. D. \& Dalton, H. Acetylene as a suicide substrate and active site probe for methane monooxygenase from Methylococcus capsulatus (Bath). FEMS Microbiol. Lett. 29, 105-109 (1985).

29. McDonald, I. R., Bodrossy, L., Chen, Y. \& Murrell, J. C. Molecular ecology techniques for the study of aerobic methanotrophs. Appl. Environ. Microbiol. 74, 1305-1315 (2008).

30. Crombie, A. \& Murrell, J. C. Development of a system for genetic manipulation of the facultative methanotroph Methylocella silvestris BL2. Methods Enzymol. 495, 119-133 (2011)

Supplementary Information is available in the online version of the paper.

Acknowledgements This work was funded by a Natural Environmental Research Council (NERC) grant (NE/E016855/1) and a NERC studentship to A.T.C. Additional funding was provided by the University of East Anglia and the Earth and Life Systems Alliance of the Norwich Research Park. We thank A. Johnston for critical reading of the manuscript.

Author Contributions A.T.C. designed and performed experiments, analysed data and wrote the paper. J.C.M. designed experiments and wrote the paper.

Author Information Reprints and permissions information is available at www.nature.com/reprints. The authors declare no competing financial interests. Readers are welcome to comment on the online version of the paper. Correspondence and requests for materials should be addressed to J.C.M. (j.c.murrell@uea.ac.uk). 


\section{METHODS}

Cultivation of Methylocella silvestris. Methylocella silvestris BL2 was grown in dilute nitrate mineral salts (DNMS) medium $(20 \mathrm{ml}$ or $25 \mathrm{ml})$ in $120-\mathrm{ml}$ serum vials sealed with rubber stoppers as previously described ${ }^{30}$ and supplied with methane or propane by injection through the septum into the headspace. Methane and propane were a minimum of $99.5 \%$ purity grade. Large-scale cultivation was carried out in 41 fermenters (LH Series 210, LH Engineering), or 21 fermenters (FerMac 300, Electrolab) supplied with methane or propane $\left(50-200 \mathrm{ml} \mathrm{min}^{-1}\right)$ and air. Other substrates were used at a concentration of $5 \mathrm{mM}$ (succinate and acetate) or $0.05 \%$ (v/v) (methanol, ethanol, 2-propanol and acetone) except where indicated. To calculate growth rates, the natural logarithm of culture density (as measured by optical density at $\left.540 \mathrm{~nm}\left(\mathrm{OD}_{540}\right)\right)$ was plotted against time, and a straight line was fitted to the exponential phase of growth using Microsoft Excel. The growth rate was determined for each culture from a minimum of three data points or two data points separated by at least $48 \mathrm{~h}$. The increase in biomass was defined as the difference between the initial and maximum densities $\left(\mathrm{OD}_{540}\right)$ reached by the culture. The consumption of methane or propane was calculated from the depletion of headspace substrate between consecutive time points during the growth phase and was plotted against the mean of the concentrations at these points. The carbon conversion efficiency was evaluated as the ratio of protein production to substrate carbon depletion.

Measurement of substrate depletion and product formation. The headspace gas concentrations were quantified using an Agilent 6890A or 7820A gas chromatograph equipped with a Porapak $\mathrm{Q}$ column (Supelco) coupled to a flame ionization detector (FID), with injector, column and detector temperatures of $150{ }^{\circ} \mathrm{C}, 125^{\circ} \mathrm{C}$ and $200^{\circ} \mathrm{C}$, respectively. Standard curves for methane and propane were prepared using standards containing known concentrations of the pure gases in air. The products of propane oxidation in the culture medium were quantified by solvent extraction. Aliquots $(1.5 \mathrm{ml})$ of the culture were centrifuged $(16,600 \mathrm{~g}, 5 \mathrm{~min}$, room temperature $\left(21^{\circ} \mathrm{C}\right)$ to pellet the cells. The supernatant $(800 \mu \mathrm{l})$ was added to $400 \mu \mathrm{l}$ ethyl acetate (containing 500 parts per million volume (p.p.m.v.) 1-butanol as an internal standard) and approximately $0.4 \mathrm{~g} \mathrm{NaCl}$, (sufficient to saturate the aqueous phase), in $1.5 \mathrm{ml}$ tubes. The samples were mixed for $30 \mathrm{~min}$ on a tube rotator and briefly centrifuged to separate the phases. An autosampler was used to inject $5 \mu$ organic phase (100:1 split) into an Agilent $7890 \mathrm{~A}$ gas chromatograph equipped with an HP-INNOWax column $(30 \mathrm{~m} \times 0.32 \mathrm{~mm} \times 0.25 \mu \mathrm{m})$ and FID. The injector temperature was $250^{\circ} \mathrm{C}$; the detector was at $250^{\circ} \mathrm{C}$; and the oven was programmed to hold at $45^{\circ} \mathrm{C}$ for $5 \mathrm{~min}$, then to increase from $45^{\circ} \mathrm{C}$ to $250^{\circ} \mathrm{C}$ at $10^{\circ} \mathrm{C} \mathrm{min}{ }^{-1}$, and then to hold at $250^{\circ} \mathrm{C}$ for $5 \mathrm{~min}$. The retention time for acetone was $2.40 \mathrm{~min}$; 1-propanol, $3.34 \mathrm{~min}$, 2-propanol, $5.40 \mathrm{~min}$; 1-butanol, $7.45 \mathrm{~min}$; and acetol, $9.70 \mathrm{~min}$. Compounds of interest were quantified using aqueous standards extracted using the same method.

Measurement of cellular protein. Total cellular protein was measured following a previously reported method ${ }^{31}$ with minor modifications. Aliquots of cultures $(500 \mu \mathrm{l})$ were stored frozen for analysis. Following thawing, $87.5 \mu 120 \%(w / v)$ SDS and $87.5 \mu \mathrm{l} 1.6 \mathrm{M} \mathrm{NaOH}$ were added, and the tubes were heated in a boiling water bath for $5 \mathrm{~min}$. The tubes were cooled, and the $\mathrm{NaOH}$ was neutralized by the addition of $87.5 \mu \mathrm{l} 1.6 \mathrm{M} \mathrm{HCl}$, centrifuged $\left(13,000 \mathrm{~g}, 5 \mathrm{~min}, 21^{\circ} \mathrm{C}\right)$, and $650 \mu \mathrm{l}$ supernatant was removed to fresh tubes. The protein was assayed using a Pierce BCA kit (Fisher Scientific), following the manufacturer's recommendations and using standards $(500 \mu \mathrm{l})$ containing $0-120 \mu \mathrm{g}$ bovine serum albumin $\mathrm{ml}^{-1}$, treated in an identical manner to the samples.

Phylogenetic analysis of MmoX and PrmA protein sequences. BLAST searches of the M. silvestris genome ${ }^{23}$ identified two putative SDIMO-encoding gene clusters: Msil_1262-Msil_1270 and Msil_1651-Msil_1646. The amino acid sequences of the putative $\alpha$-subunits, encoded by Msil1262 and Msil1651, designated $m m o X$ and $\operatorname{prmA}$ here, were combined with selected MmoX sequences from methanotrophs and related SDIMO sequences from non-methanotrophs and aligned using the Clustal program in MEGA 5 (ref. 32). Positions containing gaps or missing data were eliminated, and 356 amino acid positions in the final data set were used to construct a tree using the maximum likelihood method. Bootstrap values were based on 500 replications.

DNA and RNA methods. DNA was extracted from $M$. silvestris and manipulated using standard methods ${ }^{33}$. To visualize transcription from the $m m o X$ and $p r m A$ promoters, the vector pMHA203 (ref. 21), which contains the $m m o X$ promoter fused to the GFP gene, was modified by replacement of the $m m o X$ promoter sequence with the $\operatorname{prm} A$ promoter sequence. The primers $\operatorname{PrPf}\left(5^{\prime}\right.$-ACTCAATTGTCCGT

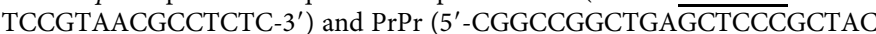
GC- $3^{\prime}$ ) were used to amplify the 1,112 base pair $(\mathrm{bp})$ promoter-containing region extending upstream from $44 \mathrm{bp} 5^{\prime}$ of the predicted start codon of $\mathrm{prmA}$. (The MunI and SacI sites are underlined.) The PCR product was cloned into PCR2.1 TOPO (Invitrogen) and excised by digestion with MunI and SacI. Following EcoRI/SacI excision of the $m m o X$ promoter region from PMHA203, the MunI/SacI fragment was ligated into these sites, resulting in pAC304. pMHA203 and pAC304 were introduced into $M$. silvestris by electroporation ${ }^{30}$, and transformed cells were selected on kanamycin-containing DNMS plates. Cells were visualized using an Axioscop fluorescence microscope (Zeiss).

Total RNA was isolated using a previously described method ${ }^{34}$ Trace residual DNA was removed by two treatments using QIAGEN RNase-free DNase, each followed by purification using an RNeasy spin column (QIAGEN). Reverse transcription was performed using SuperScript II or SuperScript III (Invitrogen), using 50-1,000 ng total RNA with $200 \mathrm{ng}$ random hexamer primers. $5^{\prime}$ RACE was performed using the 2 nd Generation $5^{\prime} / 3^{\prime}$ RACE kit (Roche), following the manufacturer's instructions, using the gene-specific antisense primers 51Ral ( $5^{\prime}$-TCGT CGTCGCATAGCACTTG-3'), 51Ra2 (5'-ATCGTGGAATGGCGGAACTC-3') and 51Ra3 (5'-TCTTCCTGCATCGGAAAGTACG-3' $\left.{ }^{\prime \prime}\right)$

Mutagenesis. Mutant strains were constructed as previously described ${ }^{30}$. For disruption of the sMMO, DNA fragments A and B (upstream and downstream of $m m o X$ ) were amplified by PCR using the primers 1262Af (5'-GATCGAGCTCCGACAC GGAAACAACCTATC-3') and 1262Ar (5'-GATCACGCGTTTCGTCGCGGT

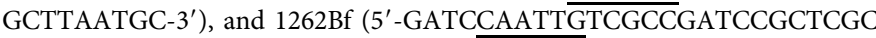
AG-3') and $1262 \mathrm{Br}\left(5^{\prime}\right.$-GATCGAATTCCGATCGAGCGCACAGCTCC-3') (restriction sites underlined). The products were cloned into pCR2.1 TOPO that had been excised with SacI/MluI and MunI/EcoRI and then ligated sequentially into pCM184 (ref. 35) that had been digested with the same enzymes. The linear SacI fragment was introduced into $M$. silvestris by electroporation, and deletion strains were selected on plates containing kanamycin. The kanamycin cassette was subsequently removed by expression of the Cre recombinase following introduction of plasmid pCM157 (ref. 35). The same procedure was followed for the deletion of prmA, using the primers 1651Af (5'-GATCGAGCTCTAGTCGGCTACGGCTATTATGG-3') and 1651Ar (5'-GAGAACGCGTGGCGCCTAACGAACTTTCTTTG-3'), and 1651Bf (5'-GATCGGTACCTCATGGGAGGCGATGGATTG- $\left.{ }^{\prime}\right)$ and $1651 \mathrm{Br}\left(5^{\prime}\right.$-GTC CGCTGACGGTGACTTTG-3'), except that the B fragment was excised from pCR2.1 TOPO using KpnI/EcoRI and ligated into these sites of pCM184. The intended gene deletions were verified by PCR using the primers $1262 \mathrm{Tf}$ ( $5^{\prime}$-CCCAGTT CCATTCGTAAGAC-3') and 1262Tr (5' -GTATTCGCTGAACAGCAAGG-3'), and 1651Tf ( $5^{\prime}$-AAGGCCGCGTCCGATACAAG- $\left.3^{\prime}\right)$ and $1651 \operatorname{Tr}\left(5^{\prime}\right.$-CAGAAC AAATCGGCCTGGGTCC- $3^{\prime}$ ), which are located outside the cloned regions, and by sequencing.

Proteomic analyses. Cells were lysed for proteomic analysis by three passages through a French pressure cell press (American Instrument Company) at $110 \mathrm{MPa}$ (on ice). Cell debris was removed by centrifugation $\left(10,000 \mathrm{~g}, 15 \mathrm{~min}, 4^{\circ} \mathrm{C}\right)$. Proteins were separated by SDS-PAGE, and bands of interest were excised from the gels for the identification of polypeptides by the Biological Mass Spectrometry and Proteomics Facility in the School of Life Sciences, University of Warwick. Coomassie-bluestained gel pieces were processed and tryptically digested using the manufacturer's recommended protocol on the MassPREP robotic protein handling system. The extracted peptides from each sample were analysed by nano liquid-chromatography electrospray-ionization tandem mass spectrometry (LC-ESI-MS/MS) using Nano Acquity/Q-Tof Ultima Global instrumentation (Waters) with a 45-min liquid chromatography gradient. All MS and MS/MS data were corrected for mass drift using reference data collected from human [ $\mathrm{Glu}^{1}$ ]-fibrinopeptide B (catalogue F3261, Sigma) sampled each minute of data collection. The data were used to interrogate an M. silvestris database appended with the common Repository of Adventitious Proteins sequences (http://www.thegpm.org/cRAP/index.html) using the ProteinLynx Global Server v2.4, as previously described ${ }^{36}$. Polypeptides were identified based on a minimum of two peptides.

Activity assays. A Clark-type oxygen electrode equipped with an OXY040A cell connected to a Digital Model 10 controller (Rank Brothers) was used to detect substrate-induced oxygen consumption by whole cells, in a $3 \mathrm{ml}$ working volume. Between $1 \mathrm{mg}$ and $5 \mathrm{mg}$ dry weight of cell suspension was added to $3 \mathrm{ml}$ oxygenated $40 \mathrm{mM}$ phosphate buffer ( $\mathrm{pH}$ 5.5) in the instrument cell maintained at $25^{\circ} \mathrm{C}$ using a circulating water bath. The instrument was operated and calibrated by comparison with air-saturated water as described previously ${ }^{37}$. The substrate (7.5$15,000 \mathrm{nmol}$ ) was added, and the substrate-induced rate was calculated by subtracting the endogenous rate from the rate following the addition of substrate. Gaseous substrates were prepared as saturated aqueous solutions in $120 \mathrm{ml}$ serum vials containing $25 \mathrm{ml}$ water flushed with at least ten volumes of the substrate gas, and the concentration was calculated using the Henry's Law constants ${ }^{22}$. Quinoprotein alcohol dehydrogenase was assayed using the artificial electron acceptor phenazine methosulphate (PMS) coupled to reduction of dichlorophenolindophenol (DCPIP), as described previously ${ }^{38}$. Reactions $(1 \mathrm{ml})$ contained $100 \mathrm{mM}$ Tris buffer (pH 9.0), $1 \mathrm{mM}$ PMS, $0.08 \mathrm{mM}$ DCPIP, $15 \mathrm{mM} \mathrm{NH}_{4} \mathrm{Cl}, 20 \mu \mathrm{g}$ protein and $10 \mathrm{mM}$ substrate. Reactions were initiated with the addition of ammonium and followed spectrophotometrically at $600 \mathrm{~nm}$. 


\section{RESEARCH LETTER}

Statistical analysis. The differences in growth rate, culture density and carbon conversion efficiency shown in Fig. 1 were evaluated using single factor analysis of variance (ANOVA) followed by Tukey's honest significant difference (HSD) method. To identify significant differences in Fig. 3, Student's $t$-test (two-tailed, two samples, assuming equal variance) was applied to the two growth conditions, using Microsoft Excel.

31. Guerlava, P., Izac, V. \& Tholozan, J.-L. Comparison of different methods of cell lysis and protein measurements in Clostridium perfringens: application to the cell volume determination. Curr. Microbiol. 36, 131-135 (1998).

32. Tamura, K., Dudley, J., Nei, M. \& Kumar, S. MEGA4: molecular evolutionary genetics analysis (MEGA) software version 4.0. Mol. Biol. Evol. 24, 1596-1599 (2007).

33. Sambrook, J., Fritsch, E. F. \& Maniatis, T. Molecular Cloning: A Laboratory Manual 3rd edn (Cold Spring Harbor Laboratory Press, 2001).

34. Gilbert, B. et al. Molecular analysis of the pmo (particulate methane monooxygenase) operons from two type ll methanotrophs. Appl. Environ. Microbiol. 66, 966-975 (2000).
35. Marx, C. J. \& Lidstrom, M. E. Broad-host-range cre-lox system for antibiotic marker recycling in Gram-negative bacteria. Biotechniques 33, 1062-1067 (2002).

36. Patel, V. J. et al. A comparison of labeling and label-free mass spectrometrybased proteomics approaches. J. Proteome Res. 8, 3752-3759 (2009)

37. Green, M. J. \& Hill, H. A. O. Chemistry of dioxygen. Methods Enzymol. 105, 3-22 (1984).

38. Anthony, C. \& Zatman, L. J. The microbial oxidation of methanol. 2. The methanol-oxidizing enzyme of Pseudomonas sp. M 27. Biochem. J. 92, 614-621 (1964).

39. Leahy, J. G., Batchelor, P. J. \& Morcomb, S. M. Evolution of the soluble diiron monooxygenases. FEMS Microbiol. Rev. 27, 449-479 (2003)

40. Coleman, N. V., Bui, N. B. \& Holmes, A. J. Soluble di-iron monooxygenase gene diversity in soils, sediments and ethene enrichments. Environ. Microbiol. 8, 1228-1239 (2006)

41. Barrios, H., Valderrama, B. \& Morett, E. Compilation and analysis of $\sigma^{54}$-dependent promoter sequences. Nucleic Acids Res. 27, 4305-4313 (1999). 


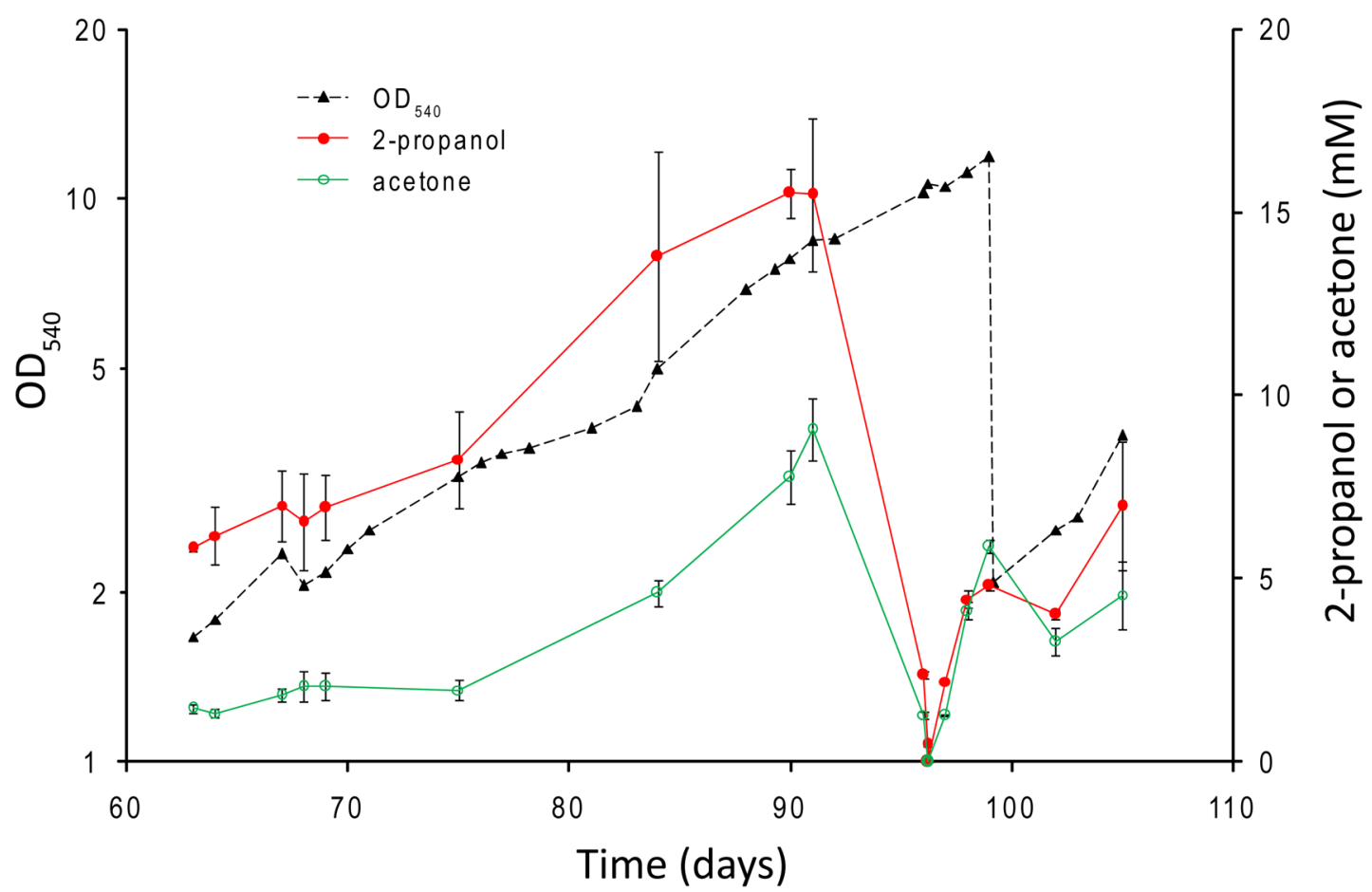

Extended Data Figure $1 \mid$ Methylocella silvestris grown on propane $(20 \%(\mathrm{v} / \mathrm{v})$ propane in air) in a fermenter (period between 62 and 106 days shown). The 2-propanol and acetone in the culture medium reached approximately $16 \mathrm{mM}$ and $9 \mathrm{mM}$, respectively. When the propane supply was shut off (days 92-96), the 2-propanol and acetone concentrations decreased to nearly zero, whereas the culture density continued to increase without interruption. Following the resumption of the propane supply, accumulation of 2-propanol and acetone was observed once again. The cells and medium were removed, and fresh medium was added on day 99 . These data demonstrate that 2-propanol and acetone result from propane oxidation and that cells growing on propane in the presence of these intermediates can metabolize them without an appreciable lag phase. The 2-propanol and acetone concentrations show the mean \pm s.d. of triplicate measurements. 


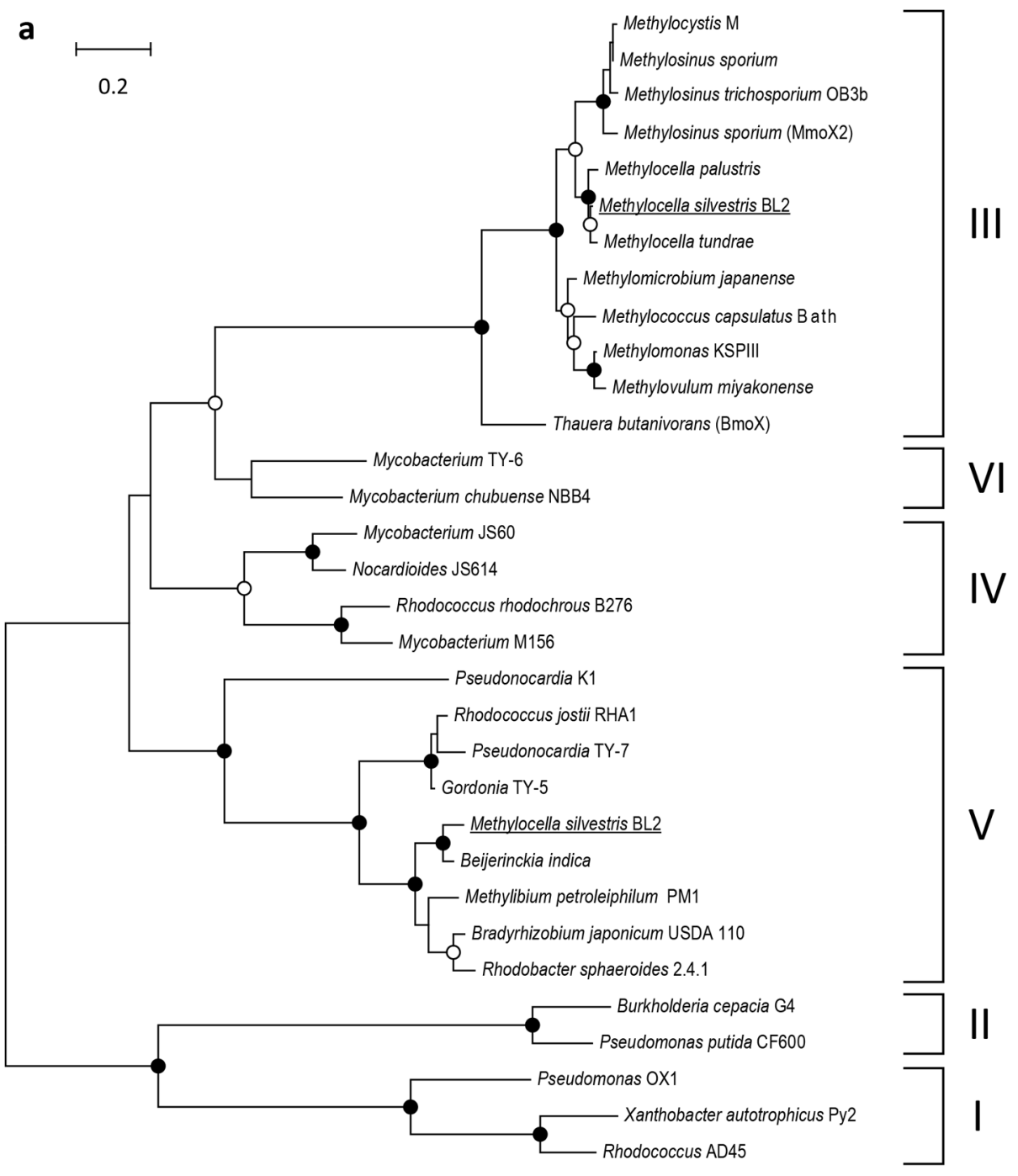

b

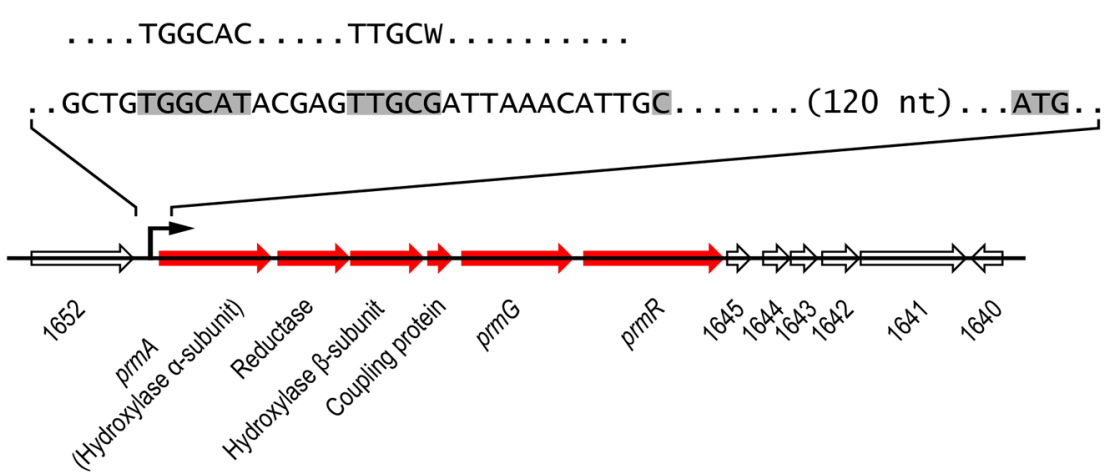

Extended Data Figure $2 \mid$ Phylogeny of SDIMOs. a, Phylogenetic relationships between the two M. silvestris SDIMOs (underlined) and other representative enzymes. The tree, constructed using the maximum likelihood method, is based on an alignment of amino acid sequences of the $\alpha$-subunit of the hydroxylases. The sequences were aligned using Clustal; positions containing gaps or missing data were eliminated; and the tree was constructed with a final data set of 356 amino acids using MEGA 5 (ref. 32). Bootstrap values (based on 500 replications) greater than $95 \%$ are shown as filled circles at nodes, and those between $75 \%$ and $95 \%$ as open circles. The SDIMO subgroups $^{39,40}$ are indicated on the right of the figure. GenBank accession numbers (in order from the top): AAC45289.1, ABD46892.1, ZP_06887019.1, ABD46898.1, CAD30366.1, YP_002361593.1, CAD88243.1, BAE86875.1,
YP_113659.1, BAA84751.1, BAJ17645.1, AAM19727.1, BAF34294.1, ACZ56324.1, AAO48576.1, YP_919254.1, BAA07114.1, AAS19484.1, CAC10506.1, YP_700435.1, BAF34308.1, BAD03956.2, YP_002361961.1, YP_001834443.1, YP_001020147.1, NP_770317.1, YP_352924.1, AAL50373.1, P19732.1, AAT40431.1, YP_001409304.1 and CAB55825.1. b, The propane monooxygenase gene cluster (shown in red). The structural genes (hydroxylase $\alpha$-subunit, reductase, hydroxylase $\beta$-subunit and coupling protein) are followed by those encoding a putative chaperone prmG (ACK50595.1) and regulatory protein $\mathrm{prmR}$ (ACK50594.1), with homology to $m m o G$ and $m m o R$ of sMMO. The putative promoter sequence is shown above in relation to the ATG start codon, together with the consensus sequence of $\sigma^{54}$ promoters as described previously ${ }^{41}$. 
a

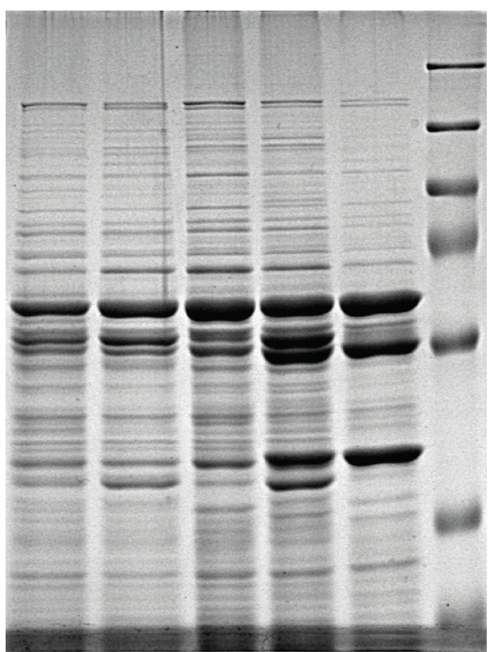

$\begin{array}{lllll}A & 2-P & S & P & M\end{array}$

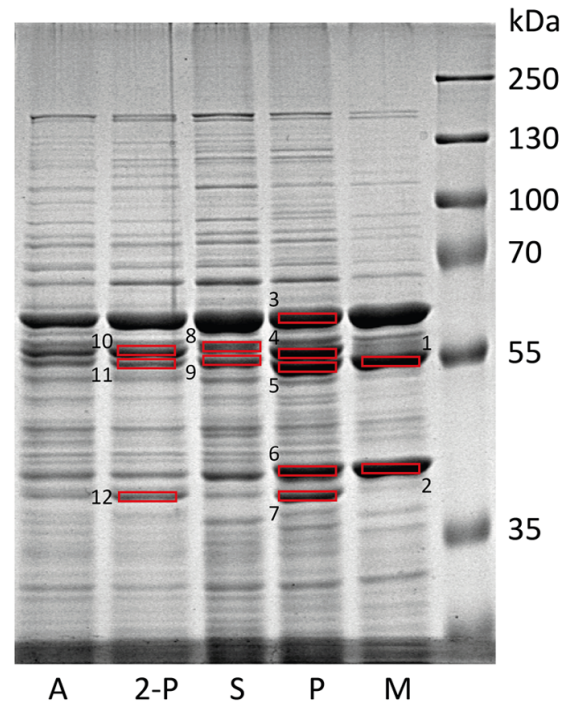

35

b

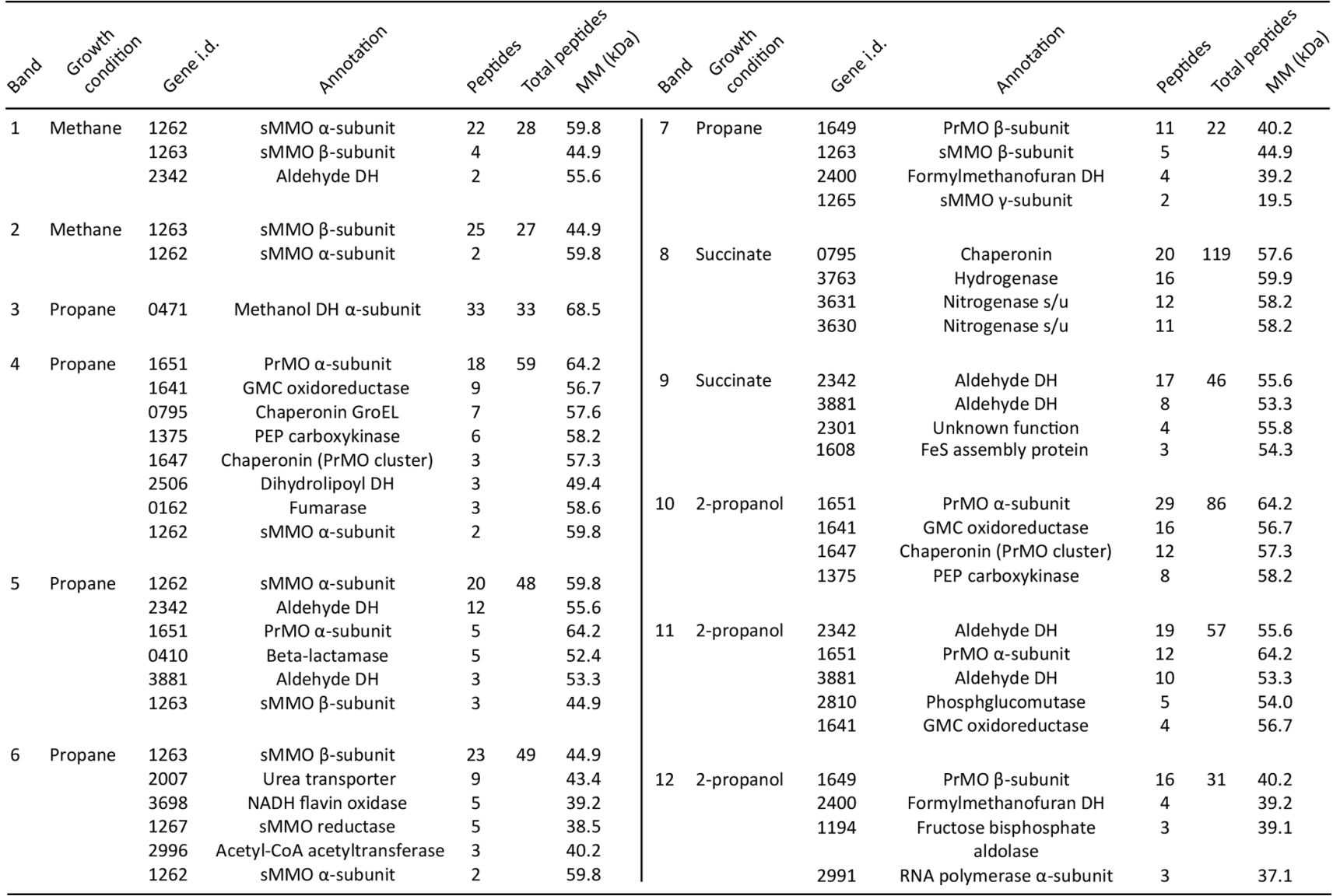

Extended Data Figure $3 \mid$ M. silvestris polypeptide profiles. a, An SDS-PAGE gel loaded with soluble extract from wild-type cells grown on methane $(M)$, propane $(\mathrm{P})$, succinate $(\mathrm{S})$, 2-propanol (2-P) or acetone $(\mathrm{A})$. Prominent bands (identified with boxes in the right-hand photograph of the same gel) evident following growth on methane or propane, but not on succinate, were excised from the gel and analysed by mass spectrometry. The polypeptide identifications are shown in $\mathbf{b}$. The data show that both sMMO and PrMO were expressed during growth on propane but that PrMO subunits were not expressed at a high level during growth on methane. PrMO subunits, but not sMMO subunits, were expressed during growth on 2-propanol. In addition, gel-free analysis of the complete soluble proteome $\mathrm{e}^{26} \mathrm{did}$ not result in the detection of PrMO polypeptides in succinate-grown or methane-grown cell extracts. b, Polypeptide identifications of the gel bands shown in a. For each band, the four most abundant polypeptides are shown, except where fewer than four were detected. In addition, all sMMO-related and PrMO-related polypeptides identified (irrespective of the number of peptides used for identification) are included. Otherwise, polypeptides identified with at least three peptides are included (except for the succinate lane; four peptides). Other identified polypeptides are not shown. The number of peptides used for the identification of each polypeptide is shown. The total number of peptides detected from all of the polypeptides identified in each band is shown for comparison. DH, dehydrogenase; MM, theoretical molecular mass; PEP, phosphoenolpyruvate. 


\section{RESEARCH LETTER}
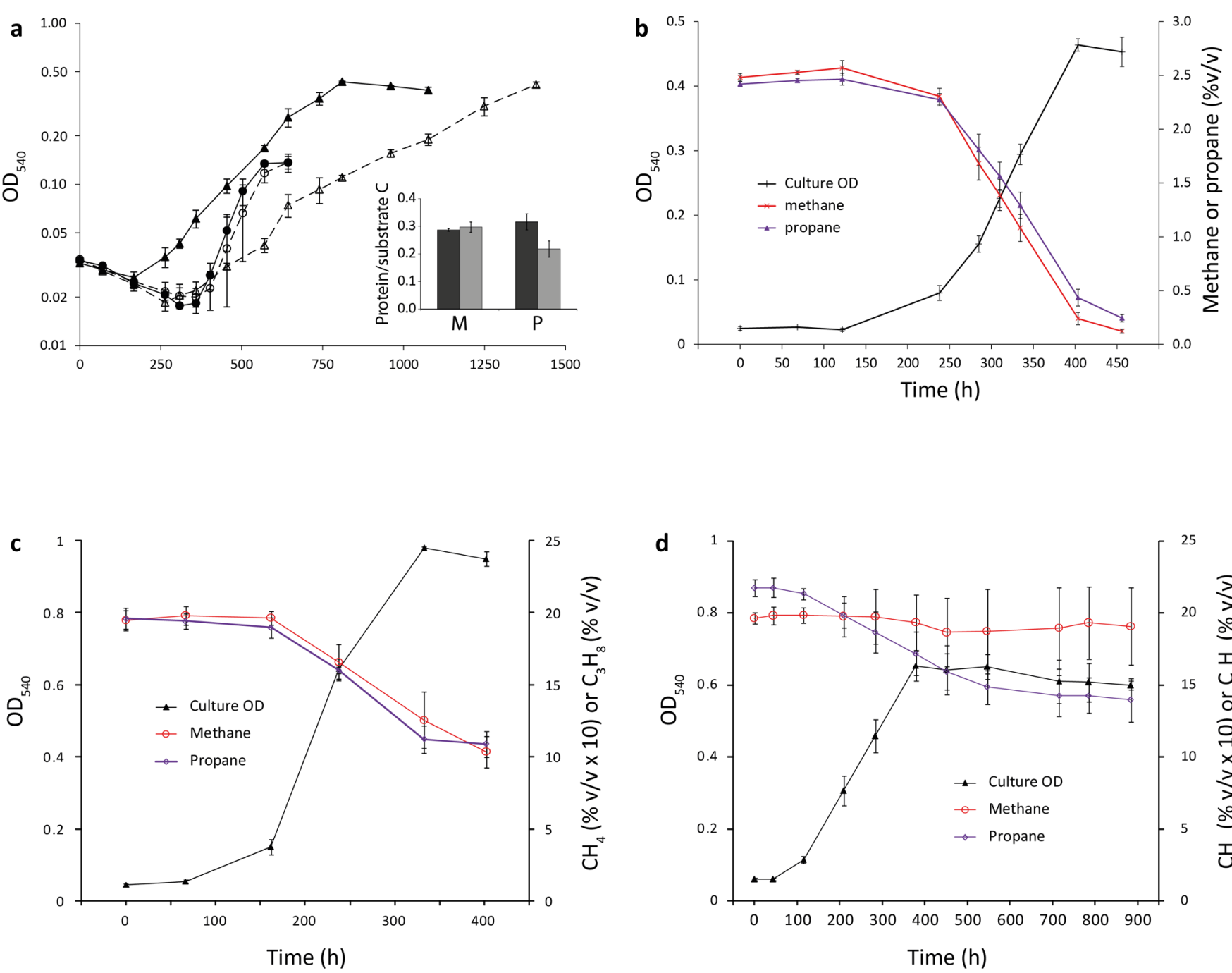

Extended Data Figure $4 \mid$ Growth of $M$. silvestris strains. a, Growth of wild-type M. silvestris (solid lines, filled symbols) and the $\triangle$ PrmA strain (dashed lines, open symbols) on methane (circles) or propane (triangles) $(2.5 \%$ $(\mathrm{v} / \mathrm{v}))$. The inset shows the substrate carbon conversion efficiency (CCE) ( $\mathrm{mg}$ of cellular protein formed per $\mathrm{mg}$ of substrate carbon consumed) for the wild-type $M$. silvestris (dark grey) and the $\Delta \mathrm{PrmA}$ strain (light grey) during growth on methane $(\mathrm{M})$ or propane $(\mathrm{P})$. Data are the mean \pm s.d. for three (methane) or two (propane) vials. b, Growth and substrate consumption of

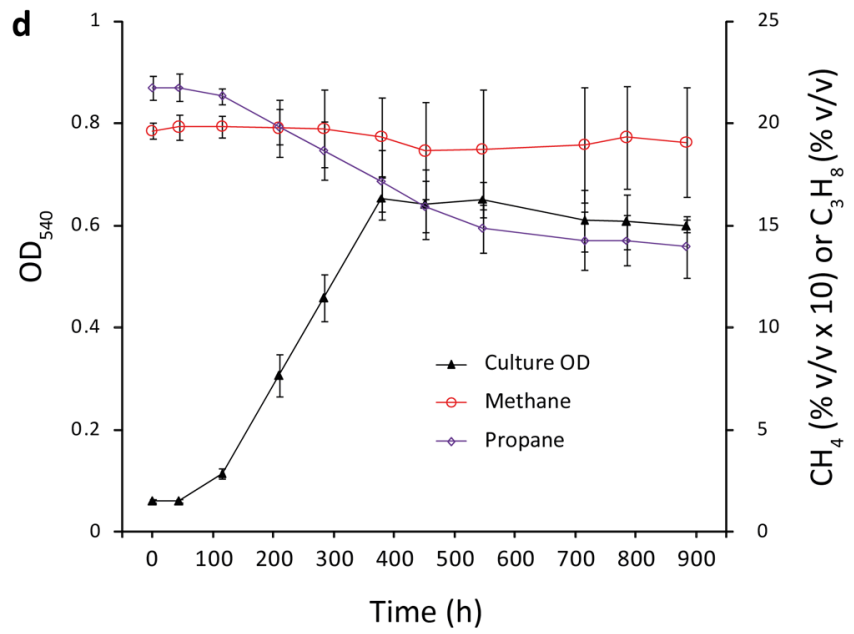

wild-type $M$. silvestris on a mixture of methane (red, crosses) and propane (purple, triangles) $(2.5 \%(\mathrm{v} / \mathrm{v})$ each). The inoculum for the cultures was grown on methane and propane $(2.5 \%(\mathrm{v} / \mathrm{v})$ each). Data points show the mean \pm s.d. of triplicate vials. c, d, Growth of and consumption of methane and propane by wild-type M. silvestris (c) and the $\Delta \mathrm{MmoX}$ strain (d) when supplied with an approximately $1: 10(\mathrm{v} / \mathrm{v})$ ratio of gases, showing that PrMO did not oxidize appreciable amounts of methane. Methane concentrations are shown as $\%(\mathrm{v} / \mathrm{v})$ $\times 10$ on the secondary (right) $y$ axes. Data are the mean \pm s.d. of triplicate vials. 


\section{a}

\begin{tabular}{cccc}
\hline Substrate for oxidation & \multicolumn{3}{c}{ Growth substrate } \\
& Methane & Propane & Succinate \\
\hline Methane & $49.0 \pm 1.2$ & $21.1 \pm 2.1$ & Not detected \\
Propane & $2.5 \pm 0.5$ & $5.9 \pm 0.8$ & Not detected \\
\hline
\end{tabular}

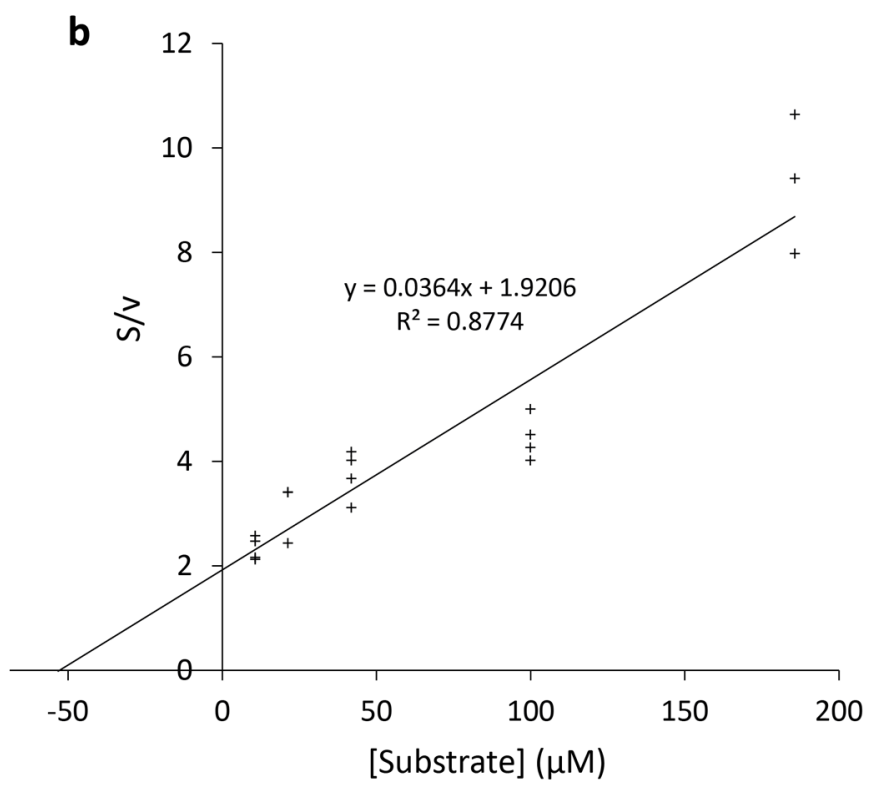

Extended Data Figure $5 \mid$ Methane and propane oxidation kinetics. a, Maximum methane-induced and propane-induced specific oxygen consumption rate (nmol $\mathrm{min}^{-1}$ per $\mathrm{mg}$ dry weight) of whole $M$. silvestris cells grown on methane, propane or succinate, as determined by oxygen electrode studies, with approximately $200 \mu \mathrm{M}$ oxidation substrate. Data are the

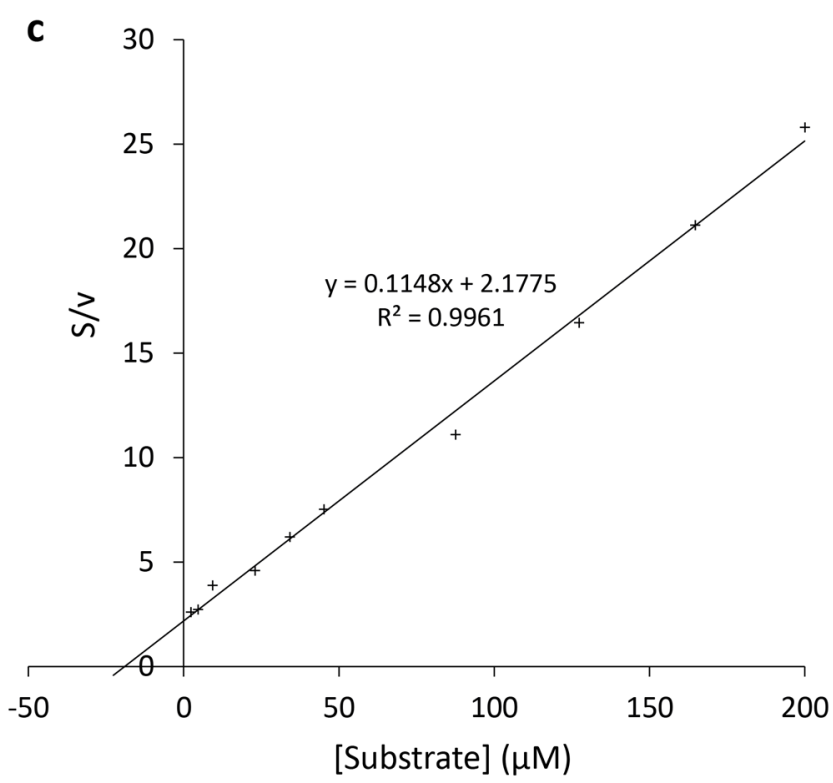

mean \pm s.d. of three measurements. $\mathbf{b}, \mathbf{c}$, Kinetics of methane-induced (b) or propane-induced (c) oxygen consumption in whole cells grown on that substrate. The Hanes-Woolf plots show substrate concentration $(S)$ divided by oxygen consumption rate $(v)$ as a function of $S$, and the trend line cuts the $x$ axis at $-K_{\mathrm{m}}$. 

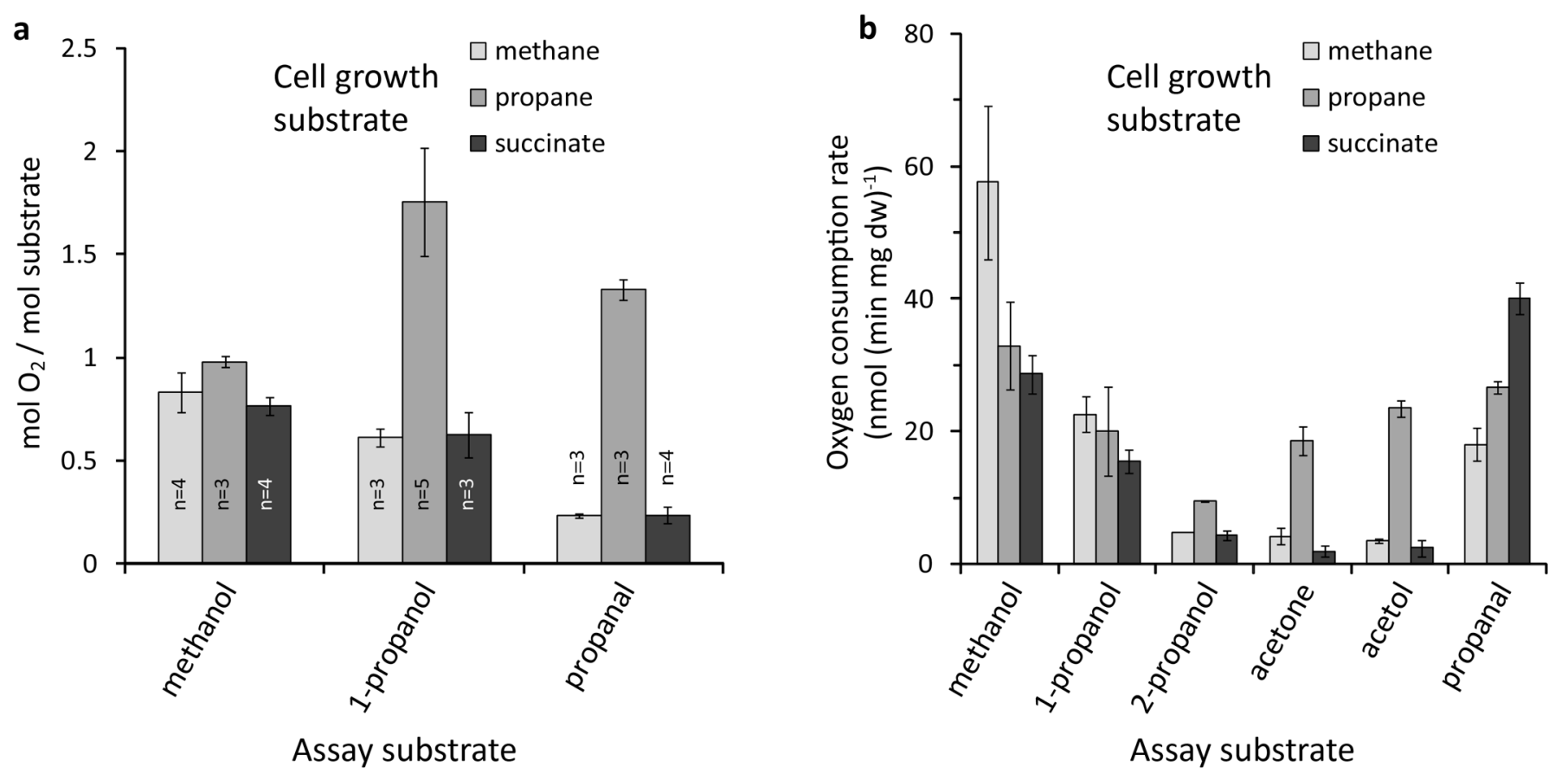

C

Growth substrate

Assay substrate

\begin{tabular}{ccc} 
& 2-propanol & 1-propanol \\
\hline methane & $63 \pm 15$ & $871 \pm 13$ \\
propane & $381 \pm 30$ & $363 \pm 7$ \\
\hline
\end{tabular}

Extended Data Figure 6 | Wild-type $M$. silvestris activity assays. a) Stoichiometry of whole-cell oxygen consumption in response to addition of 100-250 nmol methanol, 1-propanol or propanal. Cells from all growth conditions consumed approximately equimolar amounts of oxygen when methanol was added; however, when 1-propanol or propanal replaced methanol, the amount of oxygen consumed by propane-grown cells increased to threefold (1-propanol) or fivefold (propanal) that of methane-grown or succinate-grown cells. These data suggest that the oxidation of terminal intermediates proceeds further in propane-grown cells, although enzymes that can oxidize 1-propanol and propanal may be present in all cell types, as shown in $\mathbf{b}$ and $\mathbf{c}$. Data are the mean \pm s.d. of the number of measurements shown. b, Oxygen uptake rates of $M$. silvestris cells grown on methane, propane or succinate in response to the addition of the substrates shown. High rates of oxygen consumption were recorded in response to methanol, 1-propanol and propanal in cells grown on either methane, propane or succinate. However, the oxygen consumption rates in response to 2-propanol, acetone and acetol were at least twofold, fourfold or sevenfold higher, respectively, in propane-grown cells than in methane-grown or succinate-grown cells, demonstrating that the ability to oxidize intermediates of the sub-terminal oxidation pathway was induced during growth on propane. Substrates were used at a final concentration of $5 \mathrm{mM}$. Data are the mean \pm s.d. of three measurements (except for methane/methanol, $n=7$ ). c, Quinoprotein alcohol dehydrogenase activity (mean \pm s.d. of three measurements) assayed as DCPIP reduction (nmol $\mathrm{min}^{-1}$ per $\mathrm{mg}$ protein) in soluble extract from methane-grown or propane-grown cells. The activity in cell extracts from both growth conditions was high when 1-propanol was the substrate (probably as a result of the constitutive expression of methanol dehydrogenase); however, with 2-propanol as the substrate, the activity was sixfold higher in the extract from cells grown on propane than cells grown on methane. By contrast, the rates of $\mathrm{NAD}^{+}$. linked or $\mathrm{NADP}^{+}$-linked 1-propanol or 2-propanol dehydrogenase activity were less than $10 \mathrm{nmol} \mathrm{min}{ }^{-1}$ per mg protein in cell extracts from each growth condition (data not shown). 
a

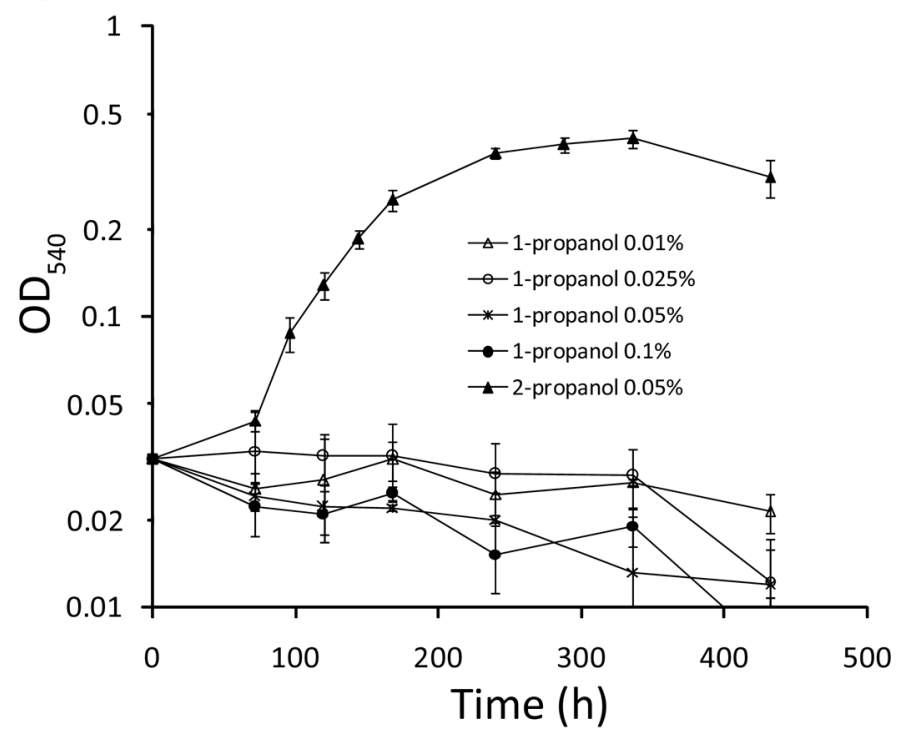

b

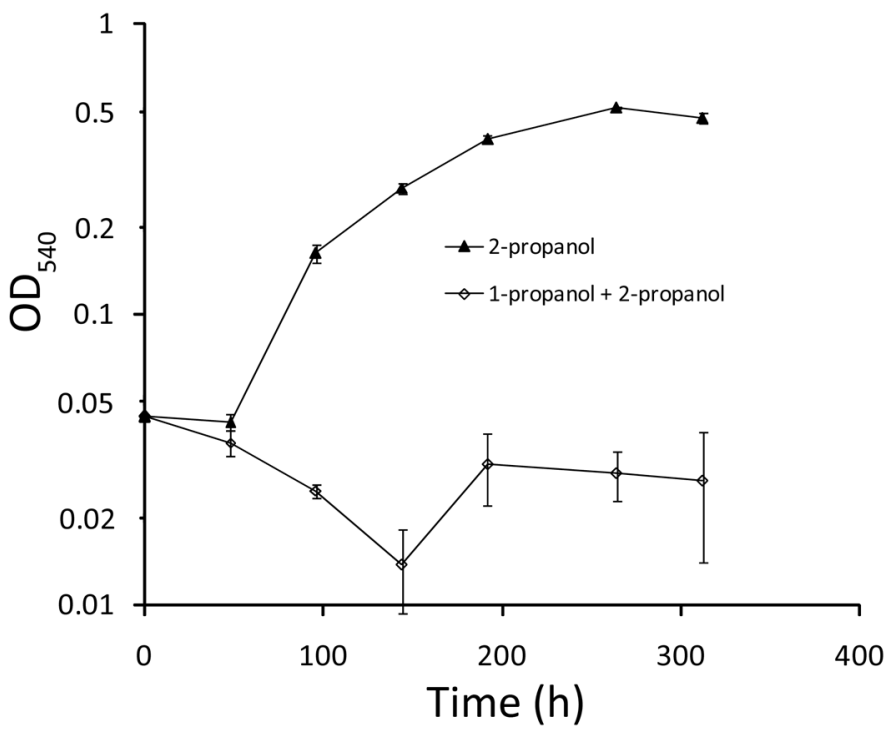

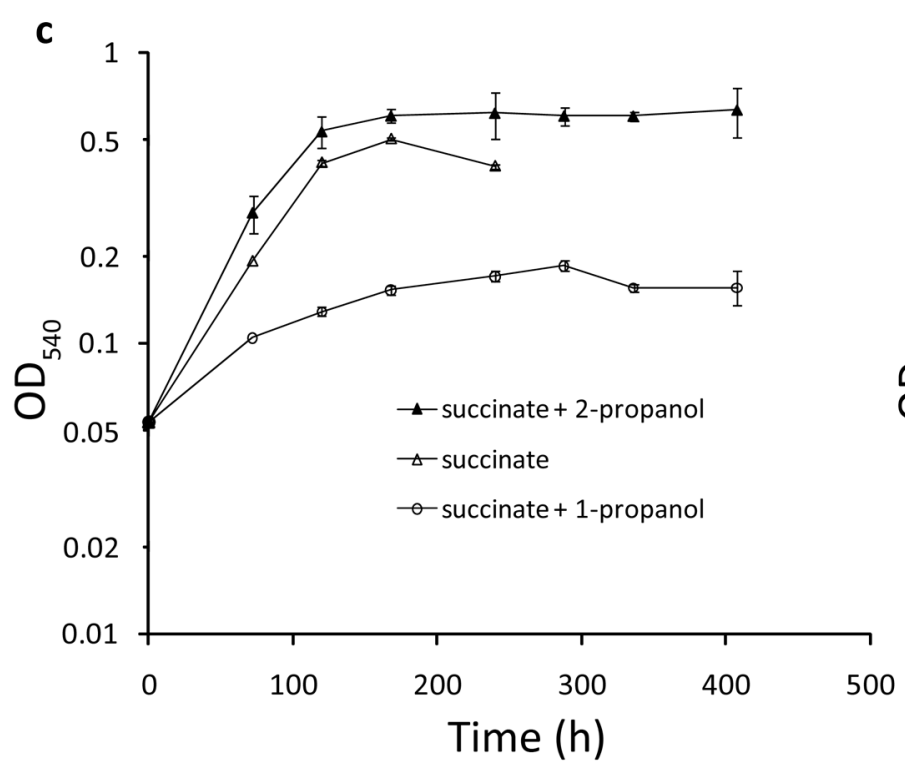

Extended Data Figure 7 1-Propanol-metabolizing ability was induced in propane-grown cells. a, When vials were inoculated with methane-grown cells, growth was possible on 2-propanol but not on 1-propanol at any concentration tested. $\mathbf{b}$, In addition, 1-propanol completely inhibited growth on 2-propanol. c, When using succinate-grown inoculum, 1-propanol also greatly inhibited growth on succinate. d, However, when using an inoculum grown on propane, limited growth occurred on 1-propanol, and 1-propanol did

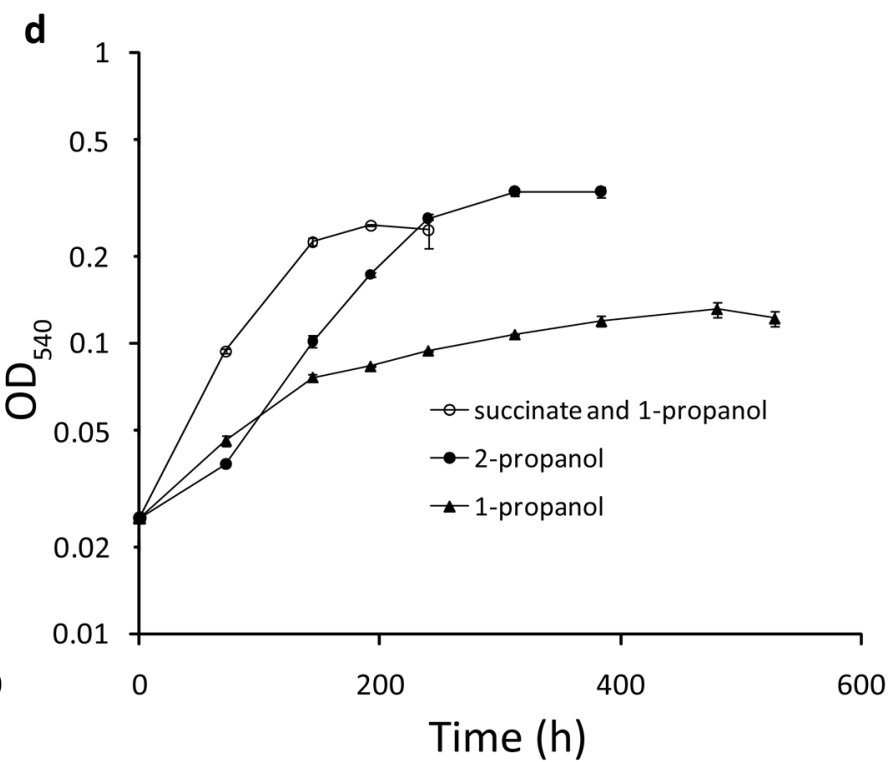

not inhibit growth on succinate, suggesting that 1-propanol-metabolizing potential was induced in cells grown on propane and could be maintained during growth on, or in the presence of, 1-propanol. The concentrations used were $0.05 \%$ (v/v) 1-propanol, 0.05\% (v/v) 2-propanol, $3 \mathrm{mM}$ succinate (except d, $5 \mathrm{mM})$, or as indicated. Data are the mean \pm s.d. of duplicate $(\mathbf{a}, \mathbf{c} \mathbf{d})$ or triplicate $(\mathbf{b})$ vials. 


\section{RESEARCH LETTER}
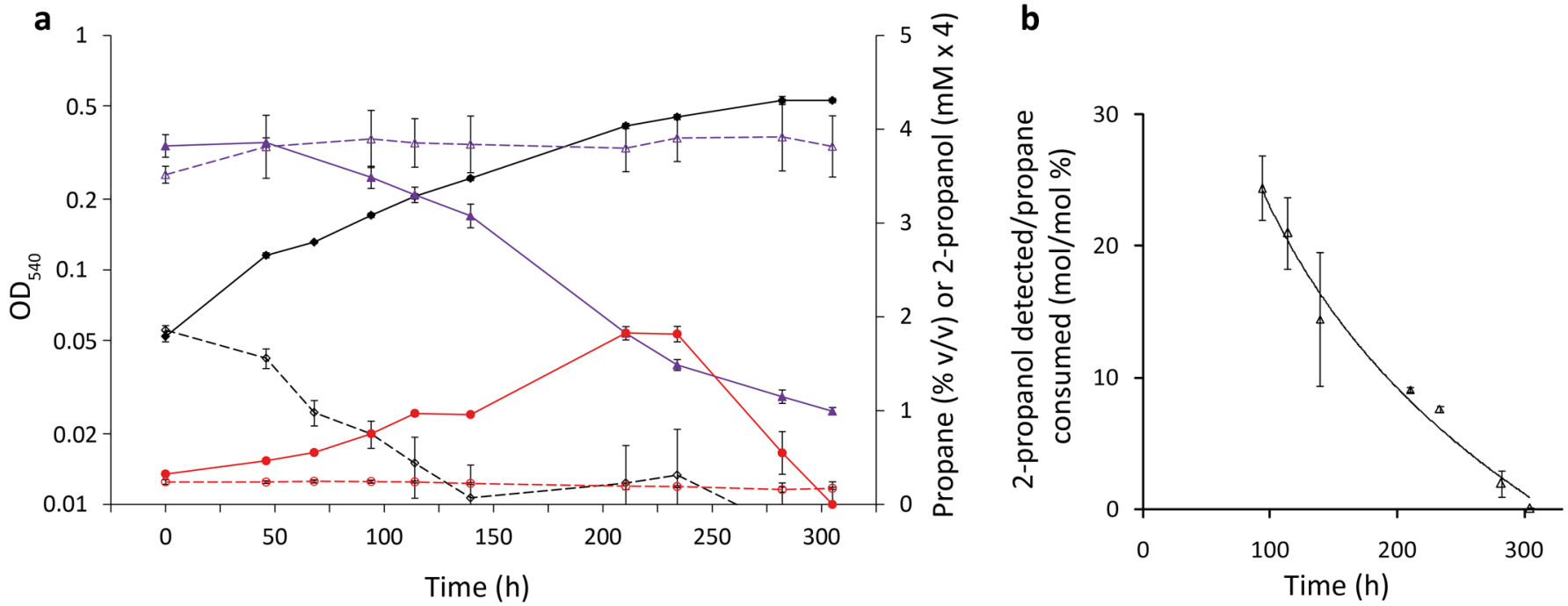

Extended Data Figure $8 \mid$ Detection of oxidation products in wild-type M. silvestris cultures. a, During growth on $4 \%(\mathrm{v} / \mathrm{v})$ propane, 2-propanol was detected in the culture medium during the mid-exponential and late exponential phase, before declining from a maximum of approximately $0.5 \mathrm{mM}$ at $210 \mathrm{~h}$ to below the limit of detection at stationary phase $(300 \mathrm{~h})$. The culture density $\left(\mathrm{OD}_{540}\right)$ is shown in black; propane concentration, in purple; and 2-propanol concentration, in red; with solid lines and filled symbols. Control vials, which contained cells killed by autoclaving, are shown as dotted lines and open symbols. The 2-propanol concentration is shown as $\times 4$ on the secondary (right) $y$ axis. Data are the mean \pm s.d. of triplicate vials. b, For the cultures shown in a, the amount of 2-propanol present at each time point (including the amount previously removed during sampling) is expressed as a percentage of the propane consumed. At $94 \mathrm{~h}, 25 \%$ of the propane consumed could be accounted for as 2-propanol in the growth medium. This value therefore represents the minimum percentage of propane that is oxidized to 2-propanol, because no allowance has been made for the consumption of 2-propanol by the cultures. Data are calculated from the mean \pm s.d. of triplicate vials. 

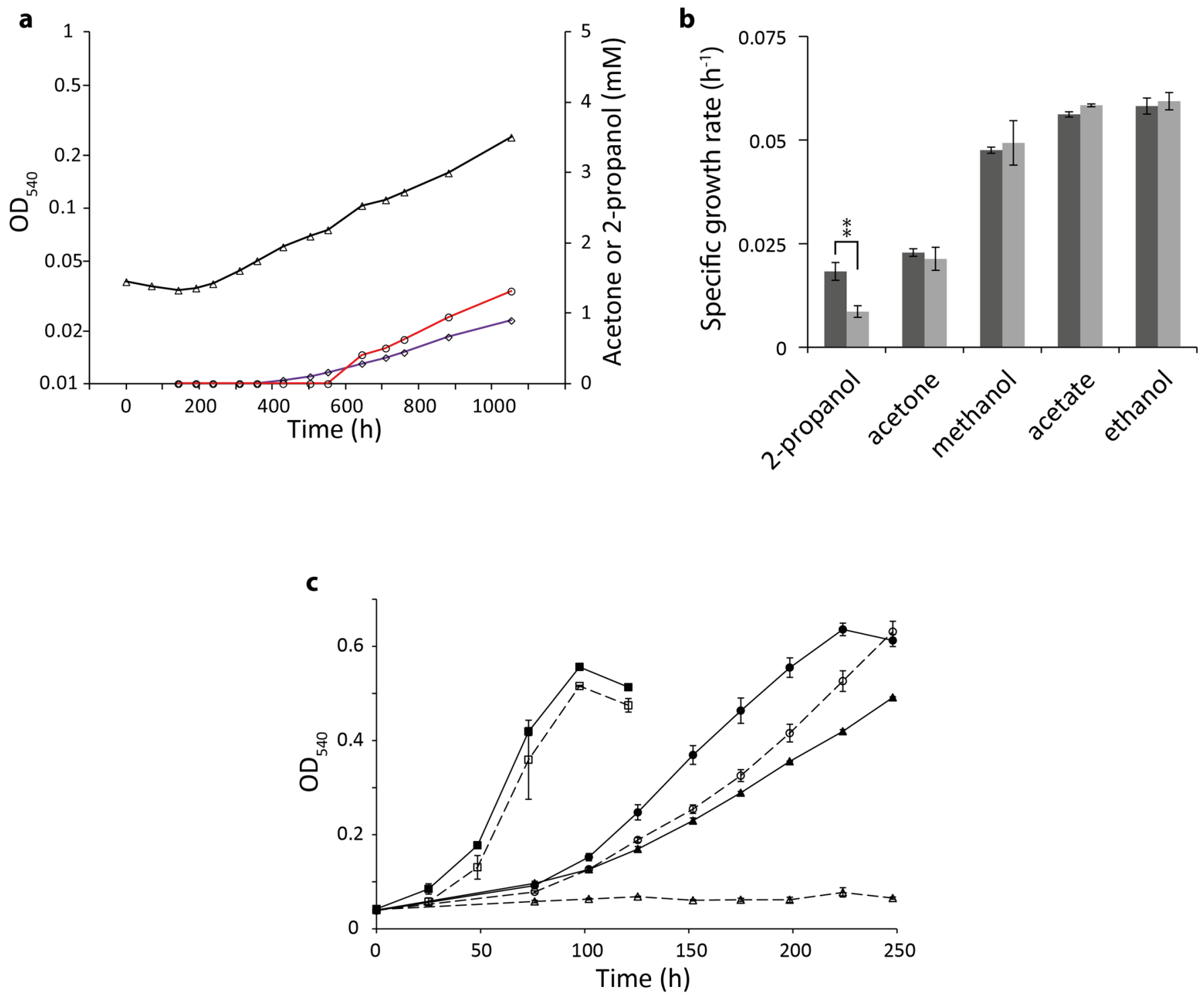

Extended Data Figure $9 \mid$ Oxidation products of the $\triangle$ PrmA strain and growth rates of the $\Delta$ PrmA, wild-type and inhibited wild-type strains.

a, Culture density (black lines, triangles) and 2-propanol (red lines, circles) and acetone (purple lines, diamonds) concentrations during growth of the $\triangle \operatorname{PrmA}$ strain on $4 \%(\mathrm{v} / \mathrm{v})$ propane. This strain accumulated $1.3 \mathrm{mM} 2$-propanol, but neither 2-propanol nor acetone were detected during growth of the $\Delta \mathrm{MmoX}$ strain on $20 \%(\mathrm{v} / \mathrm{v})$ propane (data not shown), suggesting that 2-propanol is one (or the major) product of propane oxidation by sMMO. b. Growth rate of wild-type $M$. silvestris (dark grey) and the $\triangle \mathrm{PrmA}$ strain (light grey) on the substrates shown. Disruption of PrMO decreased growth on 2-propanol compared with the wild-type, although growth on acetone, acetate, methanol or ethanol was not significantly affected, implicating PrMO in 2-propanol metabolism. Data are the mean \pm s.d. of three vials (except 2-propanol, $n=6$ ( $\triangle$ PrmA strain) or $n=5$ (wild-type)). Significance was determined by Student's $t$-test (**, $P<0.01)$. c, Growth of wild-type $M$. silvestris on acetone (squares), 2-propanol (circles) or propane $(10 \%(\mathrm{v} / \mathrm{v}))$ (triangles) either without an inhibitor (filled symbols, solid lines) or with acetylene (2\% (v/v)) as an inhibitor (open symbols, dashed lines). Data are the mean \pm s.d. of triplicate vials. For 2-propanol, the specific growth rates in the early exponential phase were $0.020 \pm 0.0002 \mathrm{~h}^{-1}$ and $0.018 \pm 0.0001 \mathrm{~h}^{-1}$ (mean \pm s.d.) for uninhibited or inhibited cultures, respectively. 


\section{RESEARCH LETTER}

Extended Data Table 1 | Substrate utilization by Methylocella silvestris

\begin{tabular}{|c|c|c|}
\hline Substrate & Concentration & Growth \\
\hline Formate & $1 \mathrm{mM}$ & - \\
\hline Formate & $5 \mathrm{mM}, 40 \mathrm{mM}$ & + \\
\hline Formate & $25 \mathrm{mM}$ & ++ \\
\hline $\mathrm{H}_{2} / \mathrm{CO}_{2}$ & $20 \% \mathrm{O}_{2}, 0.5$ to $10 \% \mathrm{CO}_{2}$, balance $\mathrm{H}_{2}$ & - \\
\hline Methane & $2.5 \%$ to $20 \%$ & ++ \\
\hline Methanol & $0.05 \%$ & ++ \\
\hline Methylamine & $5 \mathrm{mM}$ & ++ \\
\hline Acetate & $5 \mathrm{mM}$ & ++ \\
\hline Ethane & $20 \%$ & + \\
\hline Ethene & $10 \%$ & - \\
\hline Ethanol & $0.05 \%$ & ++ \\
\hline Glycine & $5 \mathrm{mM}$ & - \\
\hline Glycollate & $5 \mathrm{mM}$ & - \\
\hline Glyoxylate & $1 \mathrm{mM}, 5 \mathrm{mM}$ & - \\
\hline Oxalate & $1 \mathrm{mM}, 5 \mathrm{mM}$ & - \\
\hline Urea & $5 \mathrm{mM}$ & - \\
\hline 1,2-propanediol & $0.05 \%$ & ++ \\
\hline 1-propanol & 0.01 to $0.1 \%$ & $-^{*}$ \\
\hline 2-propanol & $0.05 \%$ & ++ \\
\hline Acetol & $0.05 \%$ & ++ \\
\hline Acetone & $0.05 \%$ & ++ \\
\hline Glycerol & $5 \mathrm{mM}$ & ++ \\
\hline Methyl acetate & $0.05 \%$ & + \\
\hline Propane & $2.5 \%$ to $20 \%$ & ++ \\
\hline Propene & $10 \%$ & - \\
\hline Propionate & $5 \mathrm{mM}$ & ++ \\
\hline Propionate & $20 \mathrm{mM}$ & - \\
\hline Pyruvate & $5 \mathrm{mM}$ & ++ \\
\hline Butane & $20 \%$ & - \\
\hline Trans-2-butene & $10 \%$ & - \\
\hline Malate & $5 \mathrm{mM}$ & ++ \\
\hline Succinate & $5 \mathrm{mM}$ & ++ \\
\hline Tetrahydrofuran & $0.05 \%$ & + \\
\hline Pentane & $0.1 \%$ & - \\
\hline Gluconate & $10 \mathrm{mM}$ & ++ \\
\hline Pentadecane & $0.1 \%$ & - \\
\hline
\end{tabular}

Growth is indicated as: ++ , growth to $\mathrm{OD}_{540}>0.25 ;+$, growth to $\mathrm{OD}_{540} \geq 0.08-0.25 ;-$, growth to $\mathrm{OD}_{540}<0.08$. (Concentrations in $\%$ are given as $v / \mathrm{v}$.) * Growth on 1-propanol was dependent on the inoculum used for the cultures. 